\title{
A Compilation of Spatial Digital Databases for Selected U.S. Geological Survey Nonfuel Mineral Resource Assessments for Parts of Idaho and Montana
}

By Mary H. Carlson ${ }^{1}$, Michael L. Zientek ${ }^{2}$, J. Douglas Causey ${ }^{2}$, Helen Z. Kayser ${ }^{3}$, Gregory T. Spanski ${ }^{4}$, Anna B Wilson ${ }^{4}$, Bradley S. Van Gosen ${ }^{4}$, and Charles M. Trautwein ${ }^{5}$

Any use of trade, firm, or product names is for descriptive purposes only and does not imply endorsement by the U.S. Government

Open-File Report 2007-1101

U.S. Department of the Interior

U.S. Geological Survey

\footnotetext{
${ }^{1}$ CACI, Spokane, WA

${ }^{2}$ U.S. Geological Survey, Spokane, WA

${ }^{3}$ Information Systems Support, Inc., Spokane, WA

${ }^{4}$ U.S. Geological Survey, Denver, CO

${ }^{5}$ U.S. Geological Survey, Sioux Falls, SD
} 


\title{
U.S. Department of the Interior DIRK KEMPTHORNE, Secretary
}

\section{U.S. Geological Survey \\ Mark D. Myers, Director}

\author{
U.S. Geological Survey, Reston, Virginia 2007
}

For product and ordering information:

World Wide Web: http://www.usgs.gov/pubprod

Telephone: 1-888-ASK-USGS

For more information on the USGS-the Federal source for science about the Earth, its natural and living resources, natural hazards, and the environment:

World Wide Web: http://www.usgs.gov

Telephone: 1-888-ASK-USGS

Suggested citation:

Carlson, Mary H., Zientek, Michael L., Causey, J. Douglas, Kayser, Helen Z., Spanski, Gregory T., Wilson, Anna B., Van Gosen, Bradley S., and Trautwein, Charles M., 2007, A compilation of spatial digital databases for selected U.S. Geological Survey nonfuel mineral resource assessments for parts of Idaho and Montana: U.S. Geological Survey Open-File Report 2007-1101 [http://pubs.usgs.gov/of/2007/1101/].

Any use of trade, product, or firm names is for descriptive purposes only and does not imply endorsement by the U.S. Government.

Although this report is in the public domain, permission must be secured from the individual copyright owners to reproduce any copyrighted material contained within this report. 


\section{Contents}

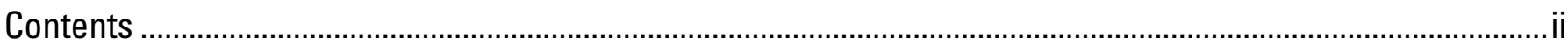

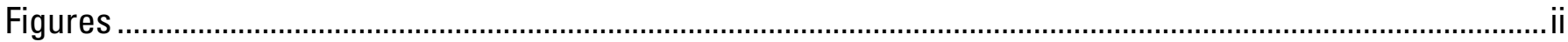

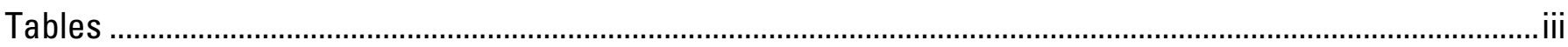

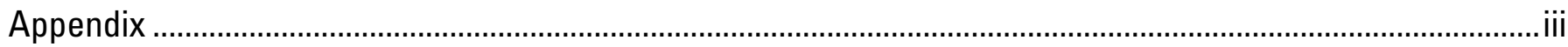

Abstract

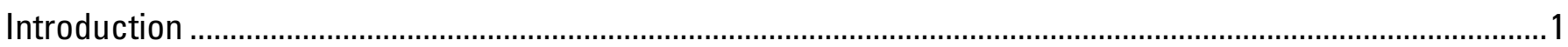

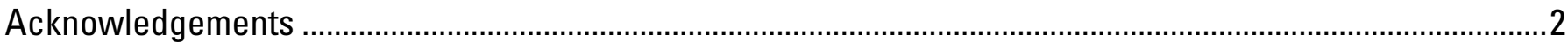

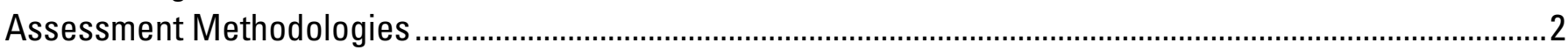

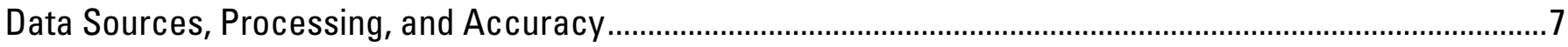

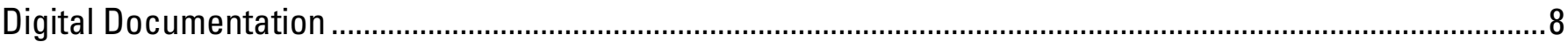

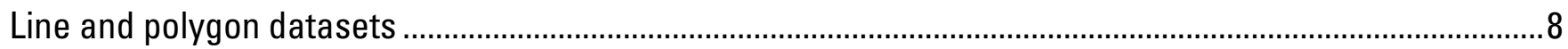

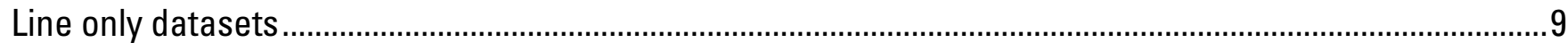

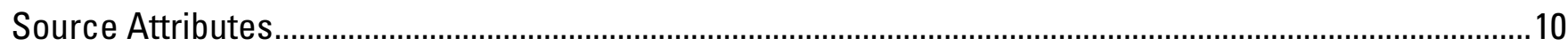

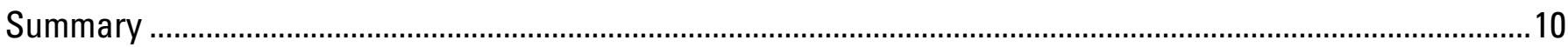

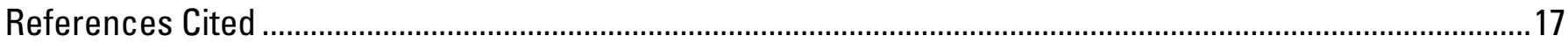

\section{Figures}

Figure 1. Sketch map of the study area, showing the locations of five study areas assessed by the USGS Conterminous Mineral Resource Assessment Program in Idaho and Montana.

Figure 2. Sketch map of the study area, showing the locations of USFS National Forest and BLM Resource Area assessments conducted by the USGS in Idaho and Montana.

Figure 3. Sketch map of the study area, showing areas identified in USGS assessments of USFS National Forests in Idaho and Montana that are permissive and favorable for undiscovered porphyry $\mathrm{Cu}$ style mineralization.

Figure 4. Sketch map of the study area, showing areas identified in USGS $1^{\circ} \times 2^{\circ}$ quadrangle assessments in Idaho and Montana that have potential for undiscovered porphyry copper-style mineralization.. 12

Figure 5. Sketch map of the study area, showing areas identified in USGS assessments of USFS National Forests in Idaho and Montana that are permissive and favorable for undiscovered sediment-hosted copper-style mineralization.

Figure 6. Sketch map of the study area, showing areas identified in USGS $1^{\circ} \times 2^{\circ}$ quadrangle assessments in Idaho and Montana that have potential for undiscovered sediment-hosted copper-style mineralization.

Figure 7. Sketch map of the study area, showing areas identified in USGS assessments of USFS National Forests in Idaho and Montana that are permissive and favorable for undiscovered sedimentary exhalative lead-zinc-style mineralization.

Figure 8. Sketch map of the study area, showing areas identified in USGS $1^{\circ} \times 2^{\circ}$ quadrangle assessments in Idaho and Montana that have potential for undiscovered sedimentary exhalative lead-zinc-style mineralization. 


\section{Tables}

Table 1. Summary of mineral resource studies that did not use the 3-part form of mineral resource assessment. 4

Table 2. Summary of user-defined items in Arclnfo arc attribute tables, ${ }^{*}$.AAT ...

Table 3. Summary of user-defined items in Arclnfo polygon attribute tables for non 3 part assessments, *.PAT.

Table 4. Summary of user-defined items in ArcInfo polygon attribute tables for three part assessments, *.PAT.

Table 5. Summary of user-defined items in Arclnfo arc attribute tables ABPLACAUG.AAT and HNFAUPLAG.AAT

Table 6. Summary of Arclnfo lookup tables, ${ }^{*}$.REF

\section{Appendix}

Appendix A. List of Arclnfo datasets representing areas of mineral potential from CUSMAP and National Forest mineral resource assessments in Idaho and Montana. 


\title{
A Compilation of Spatial Digital Databases for Selected U.S. Geological Survey Mineral Resource Assessments for Parts of Idaho and Montana
}

\author{
By Mary H. Carlson, Michael L. Zientek, J. Douglas Causey, Helen Z. Kayser, Gregory T. Spanski, Anna B \\ Wilson, Bradley S. Van Gosen, and Charles M. Trautwein
}

\section{Abstract}

This report compiles selected results from 13 U.S. Geological Survey (USGS) mineral resource assessment studies conducted in Idaho and Montana into consistent spatial databases that can be used in a geographic information system. The 183 spatial databases represent areas of mineral potential delineated in these studies and include attributes on mineral deposit type, level of mineral potential, certainty, and a reference. The assessments were conducted for five $1^{\circ}$ x $2^{\circ}$ quadrangles (Butte, Challis, Choteau, Dillon, and Wallace), several U.S. Forest Service (USFS) National Forests (including Challis, Custer, Gallatin, Helena, and Payette), and one Bureau of Land Management (BLM) Resource Area (Dillon). The data contained in the spatial databases are based on published information: no new interpretations are made. This digital compilation is part of an ongoing effort to provide mineral resource information formatted for use in spatial analysis. In particular, this is one of several reports prepared to address USFS needs for science information as forest management plans are revised in the Northern Rocky Mountains.

\section{Introduction}

Legislation to establish the U.S. Geological Survey for "classification of the public lands, and examination of the geological structure, mineral resources, and products of the national domain" was included in the bill appropriating funds for the Federal Government for the fiscal year beginning July 1, 1879. Since that time, the USGS has studied and provided impartial information on the occurrence, quality, quantity, and availability of mineral resources (Kropschot, 2006). Mineral resource assessments are one way in which this information is communicated.

This report compiles the results of two USGS programs that assessed undiscovered mineral resource potential in Idaho and Montana. The first program assessed the mineral potential of $1^{\circ} \times 2^{\circ}$ quadrangles whereas the second focused specifically on National Forests. Because USGS assessment methodology evolves, in order to meet the changing needs of the end-users and to address the quality and quantity of available information, the assessment methods for the two programs are different. However, both approaches delineate areas with potential for undiscovered mineral resources associated with a particular deposit type and estimate the degree of potential for the area.

This report compiles areas of mineral potential and their degree of potential from published mineral resource maps into consistent spatial databases. The 13 USGS mineral resource assessment areas included in this compilation are (1) the Absaroka-Beartooth study area, Custer and Gallatin National Forests (Hammarstrom and others, 1993); (2) the Dillon BLM Resource Area (Hammarstrom and others, 1999; Van Gosen and others, 1998a; Van Gosen and others, 1998b); (3) the Gallatin National Forest (Wilson and others, 2005); (4) the Helena National Forest (Tysdal and others, 1996; Green and Tysdal, 
1996); (5) the National Forest roadless areas in Idaho (Johnson and Worl, 1991); (6) the Payette National Forest (Bookstrom and others, 1998); (7) the Custer National Forest in the Pryor Mountains (Van Gosen and others, 1996); (8) the Butte $1^{\circ}$ x $2^{\circ}$ quadrangle (Elliott and others, 1992a; Elliott and others, 1992b; Elliott and others, 1993b); (9) the Challis $1^{\circ}$ x $2^{\circ}$ quadrangle (Fisher and Johnson, 1995); (10) the Challis National Forest (Worl and others, 1989); (11) the Choteau $1^{\circ}$ x $2^{\circ}$ quadrangle (Earhart and others, 1981b); (12) the Dillon $1^{\circ}$ x $2^{\circ}$ quadrangle (Pearson and others, 1990; Pearson and others, 1991; Pearson and others, 1992a; Pearson and others, 1992b); and (13) the Wallace $1^{\circ}$ x $2^{\circ}$ quadrangle (Harrison, Cressman, and others, 1986; Harrison, Domenico, and Leach, 1986a; Harrison, Domenico, and Leach, 1986b; Harrison and others, 1986a; Harrison and others, 1986b).

The mineral resource maps developed for these assessments were published in a variety of formats: most commonly as printed material, but also as spatial database files using the ESRI coverage and shapefile format, as well as the USGS GSMAP format (Selner and Taylor, 1993). This report describes the mineral resource assessments, the methods used to convert the mineral resource map data into a digital format, and the spatial database file structures and relationships. This report does not provide all digital data needed to reproduce the printed image of the resource assessment map; base material, geologic features selected from geologic maps used to provide context, or point data derived from USGS mineral occurrence databases are not included in this compilation. Spatial data commonly used as base material in printed maps may be obtained from a variety of commercial and government sources. Larsen and others (2004) and Zientek and others (2005) published digital geologic maps that cover these study areas. Mineral occurrence data from the USGS Mineral Resources Data System (MRDS) can be obtained online from http://tin.er.usgs.gov/mrds/ [Accessed November 8, 2006].

This digital compilation is part of an ongoing effort to provide mineral resource information as databases for use in spatial analysis. In particular, this is one of several reports prepared to address USFS needs for science information as forest management plans are revised in the Northern Rocky Mountains (Zientek and Kropschot, 2005). The results of mineral resource assessments will be used in conjunction with mineral deposit (Spanski, 2001; Klein, 2004, Spanski, 2004) and mining claim information (Causey, 2005) to indicate where minerals-related activities might take place in the near future.

\section{Acknowledgements}

Jeremy C. Larsen and Kenneth C. Assmus reviewed attribute information of the spatial datasets for completeness. Illustrations in this report were prepared by Kenneth C. Assmus. Pamela D. Derkey reviewed and prepared the metadata for this report. Technical reviews by Karen Bolm and Barry Moring improved the manuscript.

\section{Assessment Methodologies}

The mineral resource potential of an area is a measure of likelihood of occurrence of undiscovered minerals resources in a defined area that may become valuable within the foreseeable future (Taylor and Steven, 1983; Goudarzi, 1984). The results presented in this report derive from two different methodologies used by the USGS to assess mineral potential (Shawe, 1981; Singer, 1993). Both approaches are based on deposit models and show areas where undiscovered resources may occur.

However, they differ significantly in how they represent the potential of these areas. One method provides qualitative ranks (such as high, medium, and low) to indicate favorability (Shawe, 1981). The other method quantitatively estimates the amount of undiscovered metal that may be present (Singer, 1993).

Under the Conterminous United States Mineral Appraisal Program (CUSMAP) in the 1970s and 1980s, the USGS assessed the mineral resource potential of selected $1^{\circ}$ x $2^{\circ}$ quadrangles to assist in formulating a sound, long-range national minerals policy and to assist Federal, State, and local governments in making decisions that involve land-use planning. Selected assessment results of the Butte, Choteau, Challis, Dillon, and Wallace CUSMAP studies are included in this compilation (fig. 1, table 1). 
Although the methodology differed for each of the CUSMAP mineral resource assessments, this general procedure was followed:

1. Geologic, geochemical, geophysical, and other data pertinent to the occurrence of mineral deposits were collected and compiled.

2. The types of mineral deposits that exist and could exist in the study area were determined.

3. For each deposit type, descriptive models and recognition criteria were developed or applied.

Recognition criteria are geologic parameters that affect the favorability for the presence of a mineral deposit.

4. The areal distribution and relative importance of recognition criteria were evaluated. This resulted in the delineation of areas where undiscovered deposits could occur.

5. The mineral potential was assessed based on the presence and relative importance of recognition criteria. In this step, the areas delineated in step 4 were ranked according to their favorability for the occurrence of undiscovered mineral deposits.

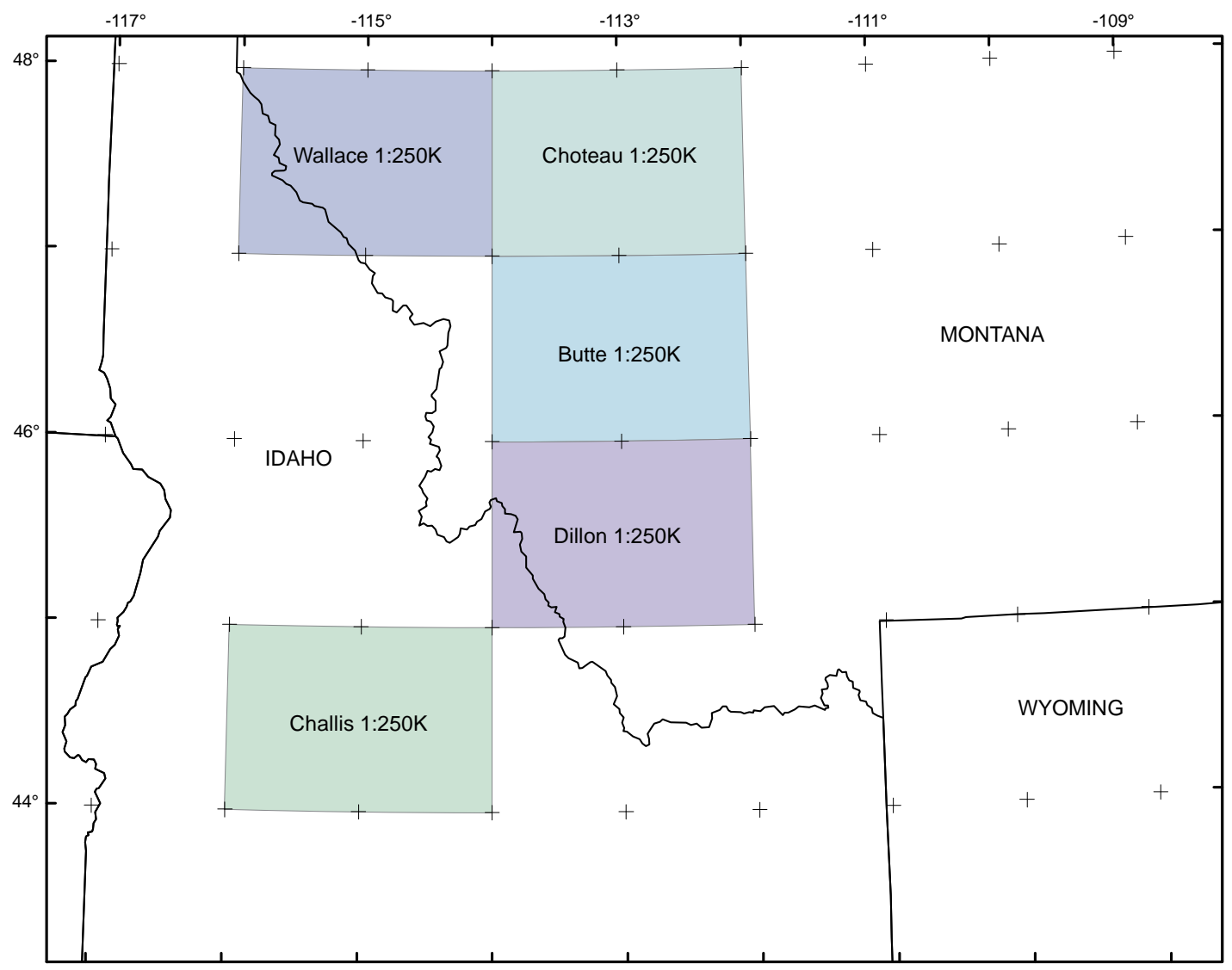

Figure 1. Sketch map of the study area, showing the locations of five study areas assessed by the USGS Conterminous Mineral Resource Assessment Program in Idaho and Montana. 
Table 1. Summary of mineral resource studies that did not use the 3-part form of mineral resource assessment.

Mineral resource
assessment study
Choteau $1^{\circ}$ x $2^{\circ}$
quadrangle,
Montana

Dillon $1^{\circ} \times 2^{\circ}$ quadrangle, Idaho and Montana

Butte $1^{\circ} \times 2^{\circ}$
quadrangle,
Montana

Assessment procedure

Areas of mineral potential inferred to be favorable for surface or near-surface ore deposits are based on geology and geochemistry. Only one area with potential for concealed porphyry deposits was outlined using geophysics.

From occurrence models, criteria were developed that allowed diagnostic data to be numerically scored. Subareas of the quadrangle were identified, outlined, and assigned numerical favorability scores. The number of different kinds of diagnostic data and the sum of favorability scores were entered into a matrix diagram that was subdivided into 7 levels of probability of ore deposit occurrence.

Descriptive models were developed for each deposit type and important characteristics (favorability criteria) relevant to the formation or localization of the deposit were identified. If the important characteristics are both few and simple or are not available at the scale of the study, the assessment was made qualitatively. If enough information was available, the resource potential was assessed using GIS procedures. For manipulation in a GIS, each criterion was weighted subjectively and given a score. The scores for each of the datasets were then summed by means of GIS and then were subjectively generalized into groups. Each group is assumed to represent a certain mineral resource potential.

Descriptive models were developed and recognition criteria were identified for each deposit type. GIS submodels were developed that correspond to these recognition criteria. Within each GIS submodel, a scoring or weighting range was generated that expresses the degree of

\section{Mineral potential terms \\ listed in decreasing order of favorability}

favorable

not ranked

highly diagnostic moderately diagnostic slightly diagnostic highly suggestive moderately suggestive slightly diagnostic no diagnostic data unfavorable

very high

high

moderate

low

very low

unknown

not classified

very high
high
moderate
low
unknown
undefined

\section{Certainty or confidence \\ of the study area as \\ defined in original publication}

geophysical extension coded in ArcInfo

dataset chotcumog

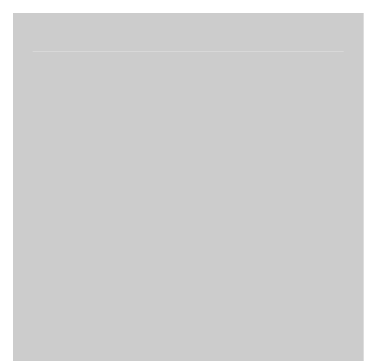

not assessed

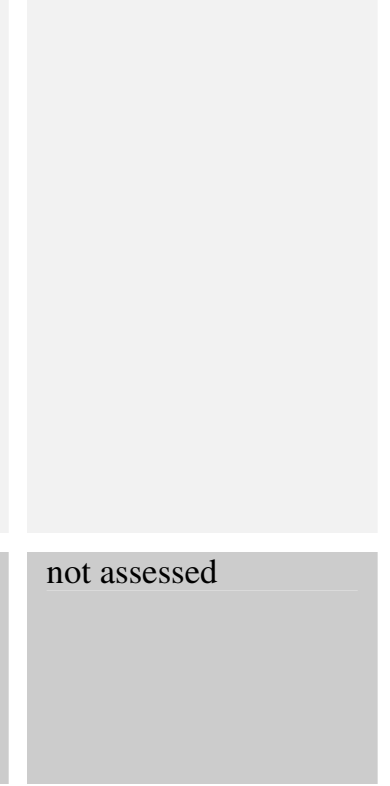

\section{Reference for assessment}

Reference for mineral

potential definitions

Earhardt and others

(1981a)

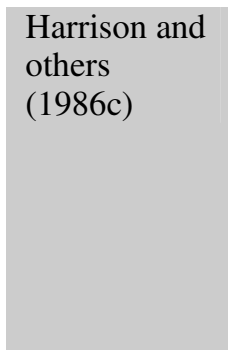

Pearson and others

(1992c)

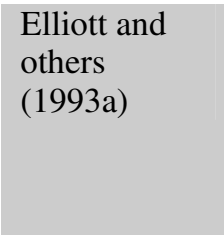

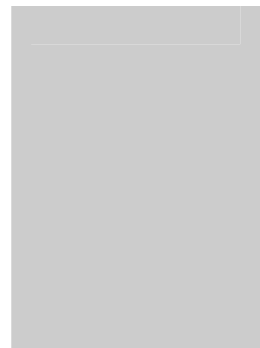

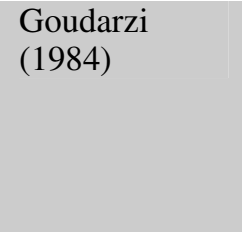


favorability. The final resource assessment maps were derived by combining the submodels into summary GIS models and then assigning levels of mineral potential to the final maps.

Challis $1^{\circ} \times 2^{\circ}$ quadrangle, Idaho

From deposit descriptions, recognition criteria were defined for each deposit type. Maps were prepared for each ore deposit type showing the distribution of mappable criteria. Areas where criteria were present were identified and scored.

The scores for each area were summed, giving an indication of relative favorability. Using these scores and any other available geologic knowledge, a resource potential was assigned to each area.

Challis National

Forest

Assessment methodology was not described but is assumed to be similar to CUSMAP studies.

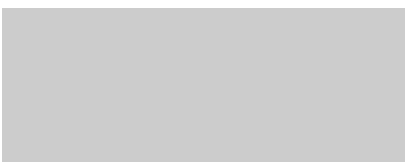

\section{high}

moderate

low

no potential

\section{high}

moderate

unknown

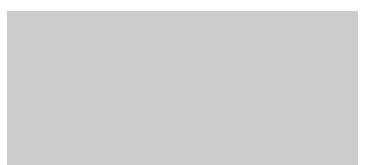

not assessed

\section{Fisher and}

Johnson

(1995)

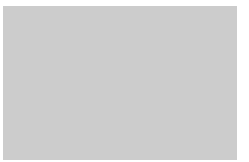

\section{Taylor and}

Steven (1983)

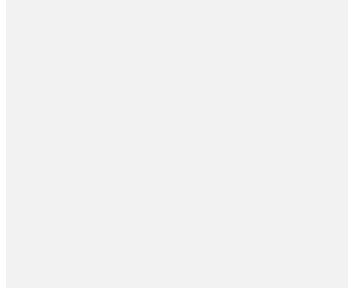

certainty ranked B

through D
Worl and

others (1989)
Goudarzi

(1984) 
The modeling approach and use of favorable criteria were first applied by Pratt (1981) to the Rolla quadrangle (Missouri). This approach was adapted and expanded to assessments conducted for the Wallace, Butte, Dillon, and Challis quadrangles (table 1). Levels of potential were defined independently for each study area; the definitions for terms indicating favorability were not systematized until late in the program. The assessments do not explicitly indicate how much undiscovered resource may be present.

Under a Memorandum of Understanding established with the USFS and the United States Bureau of Mines, the USGS conducted assessments of undiscovered mineral resources of selected National Forests beginning in the 1980s and continuing into the 1990s (fig. 2). The first forest assessments employed the methodology used by the CUSMAP studies (for example, the Challis National Forest assessment presented in this report); however, most of the studies were conducted using the 3-part form of assessment currently used by the USGS for undiscovered mineral resource assessments.

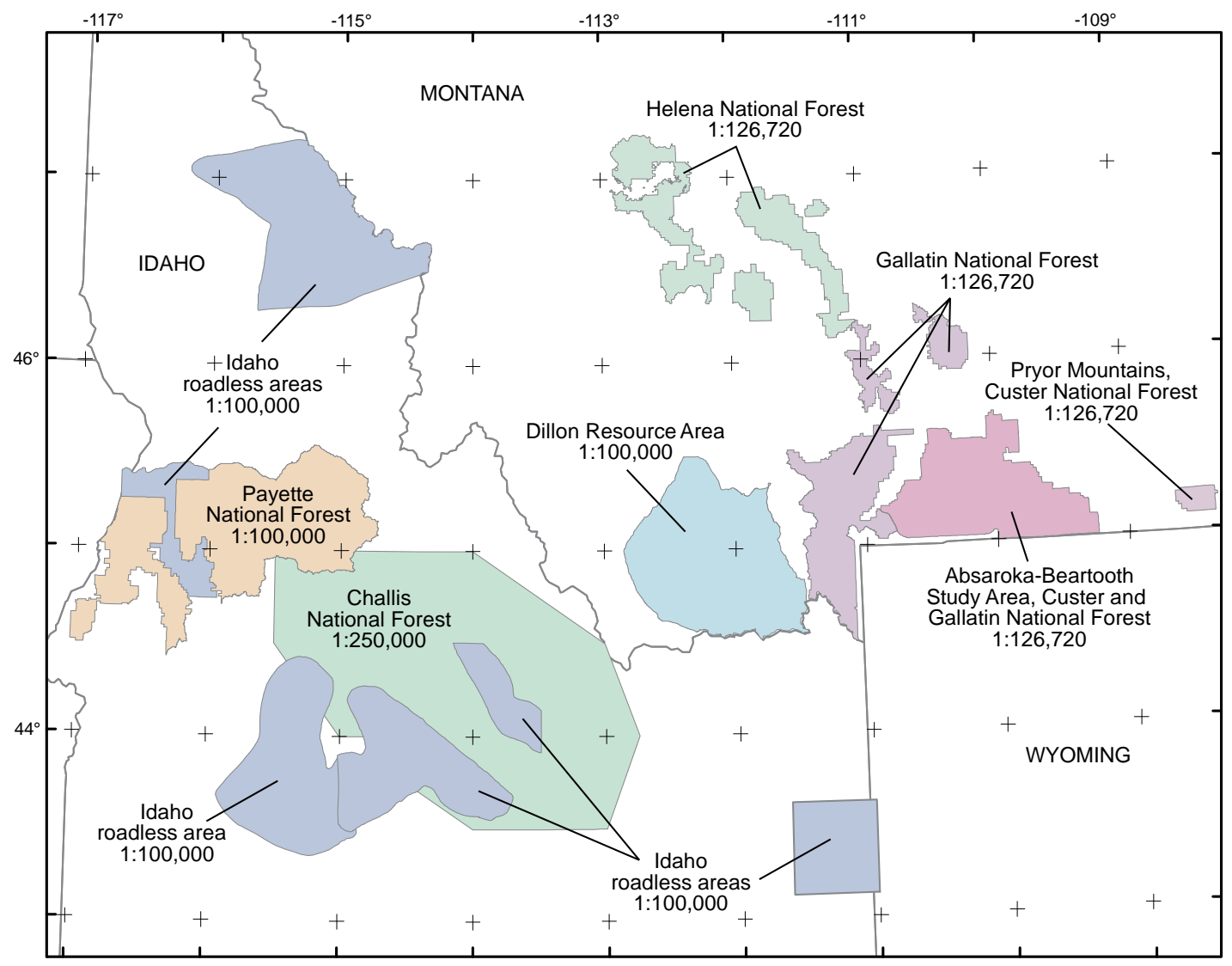

Figure 2. Sketch map of the study area, showing the locations of USFS National Forest and BLM Resource Area assessments conducted by the USGS in Idaho and Montana.

The USGS originally developed the three-part form of assessment to provide quantitative resource information in a form consistent with an economic analysis so that mineral resource values could be compared with values derived from other competing uses of land (Singer, 1993). The assessment results can be evaluated by using economic filters, cash-flow models, and other tools for application to economic, environmental, and policy analysis (Singer, 1993).

The three-part assessment method consists of the following (Singer, 1993):

1. Areas (permissive tracts) are delineated according to the types of deposits permitted by the geology, 2. The amount of metal and some ore characteristics are estimated using grade and tonnage models, and 
3. The number of undiscovered deposits of each type is estimated.

Permissive tracts are delineated for one or more deposit types so that the probability of a deposit lying outside the tract is negligible, that is, less than 1 in 100,000 to 1,000,000 (Singer, 1993). The permissive tracts included in this compilation are areas that represent the surface projection of a volume of rock, because the potential for undiscovered deposits is assessed for the uppermost kilometer of the Earth's crust. Designation of a tract as permissive does not imply any special favorability for the occurrence of a deposit, nor does it address the likelihood that a deposit will be discovered there if it exists (Singer, 1993). However, for some studies included in this report, domains within the permissive tracts were identified that showed definitive indications of mineralization consistent with the deposit type being assessed. These domains are called favorable areas within the permissive tracts.

Grade and tonnage models combined with estimates of the number of undiscovered deposits provide resource assessment results in a format that an economist can use. Grade and tonnage models have the form of frequency distributions of tonnages and average grades of well-explored deposits typical of mineral deposit type being modeled (Singer, 1993). Estimates of the number of deposits explicitly represent the probability that a fixed, but unknown, number of undiscovered deposits exist in the delineated tract. Estimates are made by deposit type and must be consistent with the grade and tonnage model. In practice, an expert panel estimates the number of deposits at various percentiles $\left(90^{\text {th }}, 50^{\text {th }}, 10^{\text {th }}\right.$, $5^{\text {th }}$, and so on) using guidelines such as 1) the frequency of known deposits in well explored areas, 2) local deposit extrapolations, 3) process constraints, 4) relative frequencies of related deposits, and 5) area spatial limits (Singer, 1993). The assessment team could also count and assign probabilities to anomalies and occurrences to come up with their estimate. Using Monte Carlo simulation, a probability distribution derived from the estimated number of undiscovered deposits is combined with grade and tonnage models to generate probability distributions of ore and metal tonnages in undiscovered deposits (Root and others, 1992).

In three part assessments, delineated tracts are consistent with descriptive models, grade and tonnage models are consistent with descriptive models, and estimates of the numbers of deposits are consistent with grade and tonnage model. This allows results of quantitative assessments to be compared between similar deposit types in differing study areas. In addition, uncertainty in the assessment is explicitly represented in the probability distributions of ore and metal tonnages.

\section{Data Sources, Processing, and Accuracy}

The primary objective of this report is to consistently represent areas of mineral potential shown in the previously published assessment reports as spatial datasets that can be used in a geographic information system (GIS). The data contained in the spatial databases is based on published information: no new interpretations are made. The spatial databases in this report delineate the areas of mineral potential shown on maps in the source assessment reports. For each study area, every deposit type assessed is represented by a separate spatial database. Each spatial database has a consistent set of polygon or arc attributes stored in associated tables. The attribute tables provide information on the deposit type being assessed, the assessment method, the mineral potential rank, and a reference to the assessment report. 183 spatial databases were created for this study (Appendix A).

The first step in preparing this report was to convert all the published assessment results into ArcInfo coverages. The assessment results were available in a variety of formats: paper maps, GSMAP files, ESRI files, and raster images. Results available only as paper maps were digitized, either by the USGS or a vendor, Optronics Specialty Co., Inc. Only some of the digital files have been published; for some study areas, authors of the assessment reports provided us with GIS files they used to create maps and illustrations in their publications. GSMAP files were converted to ArcInfo coverages using conversion software. Raster datasets for the Butte and Dillon CUSMAP studies were vectorized and saved as ArcInfo coverages. 
Next, a spatial database was created for each deposit type in a study area. Tracts with potential for multiple deposit types that were combined on a single assessment map were separated. Some areas have potential for more than one deposit type; in this situation, multiple spatial databases were created so that every deposit type had its own separate spatial database.

Study area boundaries were then added to each dataset. The study area boundaries for the National Forests and the 1:100,000 scale maps already existed so they were just combined with the associated datasets. The boundaries for the 1:250,000 scale maps had to be mathematically generated using ArcInfo before combining with the associated datasets.

All datasets utilizing the same assessment methodology were attributed with a common data structure. The attribute table structure for the CUSMAP studies and the Challis National Forest (non-3 part assessments) are identical; similarly, the table structure for all the studies conducted with the 3-part methodology are the same (Absaorka-Beartooth study area, Custer and Gallatin National Forests; Pryor Mountains study area, Custer National Forest; Gallatin National Forest; Helena National Forest; Dillon BLM Resource area; and roadless areas in Idaho national forests).

Finally, each dataset was converted from its original projection to geographic coordinates. The digital files were then plotted and compared to the original maps to check for digitizing and attributing errors. Accuracy was estimated by comparing paper plots to the original mineral potential maps and measuring offset at 10 locations. The overall accuracy (with respect to the location of lines) of the spatial databases ranges between 0 and 6,600 meters depending on the spatial database. Refer to Appendix A for documentation on how each of the original publications was processed and the accuracy of individual datasets.

\section{Digital Documentation}

This report has 183 spatial databases representing the results of mineral resource assessments; most databases are line and polygon datasets that represent areas of mineral potential. Only two datasets are line datasets, which represent stream segments with potential for placer gold mineralization.

\section{Line and polygon datasets}

These datasets are comprised of polygons delineating areas with potential for a specific deposit type and arcs describing the types of boundaries separating the polygons. The attributes for the polygons are stored in a polygon attribute table, *.PAT. Arcs are described by an arc attribute table, *.AAT. Both the polygon and arc attribute tables refer to ArcInfo lookup tables, *.REF, which contain reference information. Descriptions of the items identifying linear features, such as boundaries (for example, study area boundary, mineral potential boundary) in the arc attribute table, *.AAT, are given in table 2.

Table 2. Summary of user-defined items in Arclnfo arc attribute tables, *.AAT

\begin{tabular}{|l|l|}
\hline \multicolumn{1}{|c|}{\begin{tabular}{c}
\multicolumn{1}{c|}{ ITEM } \\
NAME
\end{tabular}} & \multicolumn{1}{c|}{ AATRIBUTE DESCRIPTION } \\
\hline linecode & Integer that identifies type of linear feature. \\
\hline desc & Description of linear feature. For example, study area boundary, mineral potential boundary. \\
\hline source & $\begin{array}{l}\text { Integer that identifies the data source for the assessment. See ArcInfo lookup table *.REF for complete } \\
\text { references. }\end{array}$ \\
\hline
\end{tabular}

Descriptions of the polygon attribute table for areas of undiscovered mineral resource potential delineated in the non-3 part assessment studies (CUSMAP studies and the Challis National Forest) are given in table 3. 
Table 3. Summary of user-defined items in Arclnfo polygon attribute tables for non 3 part assessments, *.PAT.

\begin{tabular}{|l|l|}
\hline \multicolumn{1}{|c|}{\begin{tabular}{l|} 
ATEMM \\
NAME
\end{tabular}} & \multicolumn{1}{c|}{ ATRATBUTE DESCRIPTION } \\
\hline code & Map symbol used to label the unit on the original resource potential map. \\
\hline dep_type & The name of the deposit type that was assessed. See original reports for deposit type description. \\
\hline tract & The name applied to subsets of polygons in the original study. \\
\hline source & $\begin{array}{l}\text { Integer that identifies the data source for the assessment. See ArcInfo lookup table *.REF for complete } \\
\text { references. }\end{array}$ \\
\hline asses_rank & $\begin{array}{l}\text { Term that describes the level of mineral resource potential, for example, low, moderate, high. Refer to original } \\
\text { reports for definitions. }\end{array}$ \\
\hline cert_rank & $\begin{array}{l}\text { Term that describes the certainty level associated with the assessment of mineral potential. For the Challis } \\
\text { National Forest, certainty ranks are B, C, and D. Refer to definitions in Goudarzi (1984, p. 8). For the Choteau } \\
\text { quadrangle, gpext indicates geophysical extention of tract. }\end{array}$ \\
\hline asses_typ & Type of assessment, in this case, non 3-part. \\
\hline
\end{tabular}

Descriptions of the polygon attribute table, *.PAT for areas of undiscovered mineral resource potential for the 3 part assessment studies are given in table 4 .

Table 4. Summary of user-defined items in ArcInfo polygon attribute tables for three part assessments, *.PAT.

\begin{tabular}{|l|l|}
\hline \multicolumn{2}{|c|}{ ATTRAT } \\
\hline ITEM NAME & \multicolumn{1}{c|}{ ATRIB DESCRIPTION } \\
\hline $\begin{array}{l}\text { model_ } \\
\text { name }\end{array}$ & $\begin{array}{l}\text { The name of the published USGS deposit model that was assessed. No entry indicates } \\
\text { that an informal deposit type was assessed. }\end{array}$ \\
\hline model_no & $\begin{array}{l}\text { The published USGS deposit model number. No entry indicates an informal deposit type } \\
\text { was assessed. }\end{array}$ \\
\hline model_source & $\begin{array}{l}\text { Integer that identifies the data source for the deposit model. See ArcInfo lookup table } \\
\text { *.REF for complete references. No entry indicates an informal deposit type was assessed. }\end{array}$ \\
\hline code & Map symbol used to label the unit on the original resource potential map. \\
\hline dep_type & $\begin{array}{l}\text { The name of the informal deposit type that was assessed. See original reports for deposit } \\
\text { type description. No entry indicates a published USGS deposit model was assessed. }\end{array}$ \\
\hline tract & The name applied to subsets of polygons in the original study. \\
\hline source & $\begin{array}{l}\text { Integer that identifies the data source for the assessment. See ArcInfo lookup table *.REF } \\
\text { for complete references. }\end{array}$ \\
\hline asses_rank & $\begin{array}{l}\text { Term that describes the level of mineral resource potential, for example, permissive or } \\
\text { favorable. See text and Singer (1993) for definitions. }\end{array}$ \\
\hline asses_typ & Type of assessment, in this case, 3-part. \\
\hline
\end{tabular}

\section{Line only datasets}

Two assessment datasets, ABPLACAUG and HNFAUPLAG, are comprised only of arcs delineating potential for placer gold. They are described by an arc attribute table, *.AAT, that refers to ArcInfo lookup tables, *.REF. Descriptions the arc attribute table for these datasets are given in table 5. 
Table 5. Summary of user-defined items in Arclnfo arc attribute tables ABPLACAUG.AAT and

HNFAUPLAG.AAT.

\begin{tabular}{|l|l|}
\hline \multicolumn{2}{|c|}{ ABPLACAUG.AAT and HNFAUPLAG.AAT } \\
\hline \multicolumn{1}{|c|}{ ATEM NAME } & \multicolumn{1}{c|}{ ATRIBUTE DESCRIPTION } \\
\hline linecode & Integer that identifies type of linear feature. \\
\hline desc & $\begin{array}{l}\text { Description or explanation of linear feature. For example, study area boundary, stream } \\
\text { segment. }\end{array}$ \\
\hline dep_type & $\begin{array}{l}\text { The name of the informal deposit type that was assessed, in this case, placer gold. See } \\
\text { original reports for deposit type description. }\end{array}$ \\
\hline tract & The name applied to subsets of arcs in the original study. \\
\hline source & $\begin{array}{l}\text { Integer that identifies the data source for the linear feature. See ArcInfo lookup tables } \\
\text { ABPLACAU.REF and HNFPLAAU.REF for complete references.. }\end{array}$ \\
\hline asses_rank & $\begin{array}{l}\text { Term that describes the level of mineral resource potential, for example, permissive. See } \\
\text { text and Singer (1993) for definitions. }\end{array}$ \\
\hline asses_typ & Type of assessment, in this case, 3-part. \\
\hline
\end{tabular}

\section{Source Attributes}

Descriptive source or reference information for the spatial datasets is stored in the ArcInfo lookup tables *.REF. Attribute descriptions for items in the *.REF data source files are given in table 6.

Table 6. Summary of Arclnfo lookup tables, ${ }^{*}$.REF.

\begin{tabular}{|l|l|}
\hline \multicolumn{2}{|l|}{} \\
\hline ITEM NAME & ATTRIBUTE DESCRIPTION \\
\hline source & Integer that identifies the data source. \\
\hline scale & Source scale of the mineral resource map. \\
\hline authors & Author(s) or compiler(s) of source map entered as last name, first name or initial, and middle initial. \\
\hline year & Source (map) publication date \\
\hline reference & Remainder of reference in USGS reference format. \\
\hline
\end{tabular}

\section{Summary}

In the years following the USGS mineral resource assessments, GIS has become an essential part of the land-use planning process, allowing spatial information from many disciplines to be compared and integrated. Although the results of these mineral assessment studies were available in published reports and maps, their impact in the land-use planning process was lessened because the data was not available in a digital format amenable to spatial analysis. This report begins the process of providing these mineral assessment results in a format that can be used in GIS-based land-use planning efforts.

This report displays the areas of mineral potential and provides attribute information about the type of mineralization that may be present, the level of potential, and a reference. As an example of the type of results that can be derived from these datasets, figures 3 and 4 illustrate the mineral potential associated with porphyry copper-type mineralization, figures 5 and 6 illustrate the assessments results for sedimenthosted copper-type mineralization, and figures 7 and 8 show results for sedimentary exhalative lead-zinctype mineralization. However, these datasets are limited because they do not convey the depth of information that is available in the original reports. Users of these datasets should refer to the published assessment results, particularly those in which quantitative estimates of the amounts of undiscovered resources were made. 


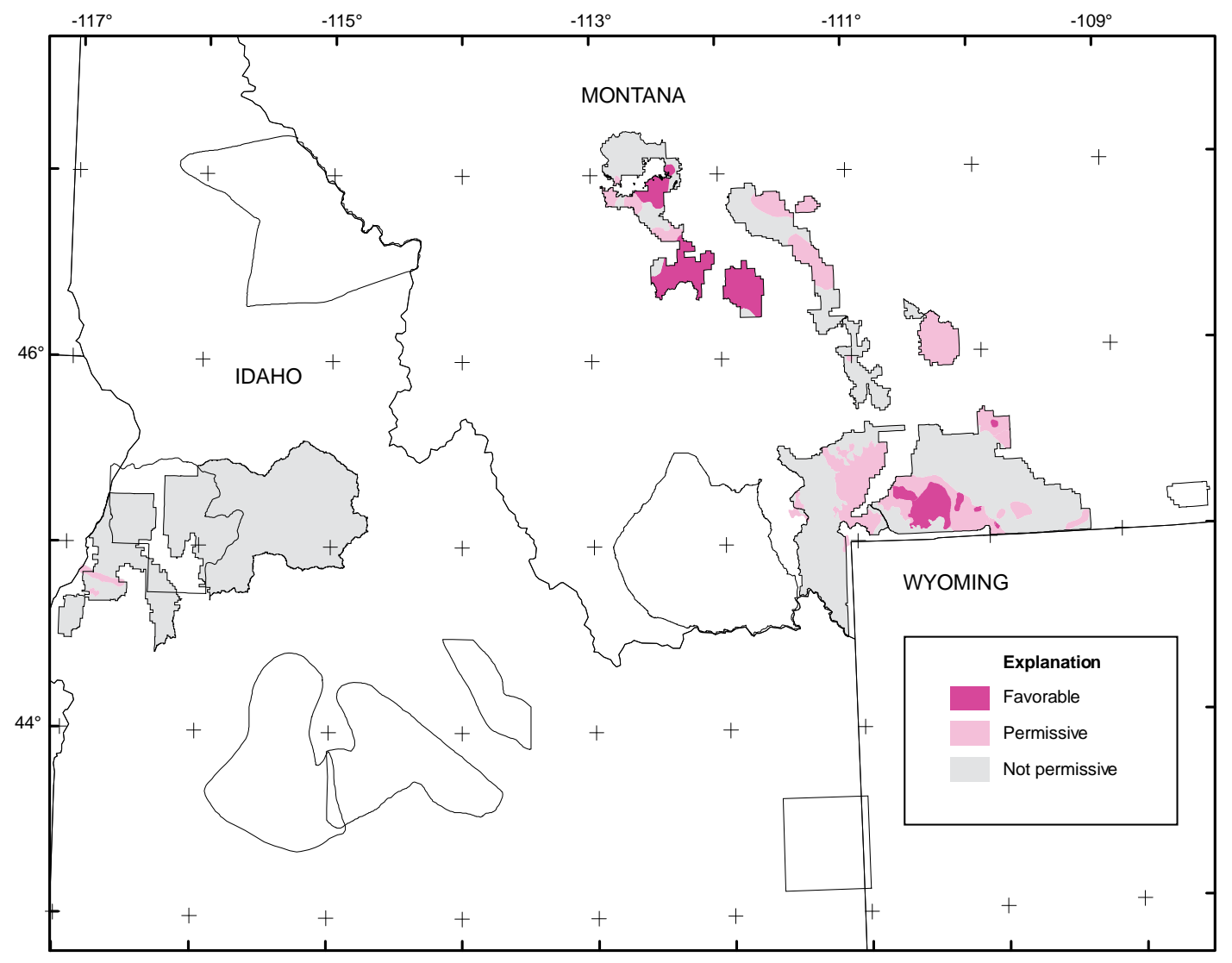

Figure 3. Sketch map of the study area, showing areas identified in USGS assessments of USFS National Forests in Idaho and Montana that are permissive and favorable for undiscovered porphyry Cu-style mineralization. 


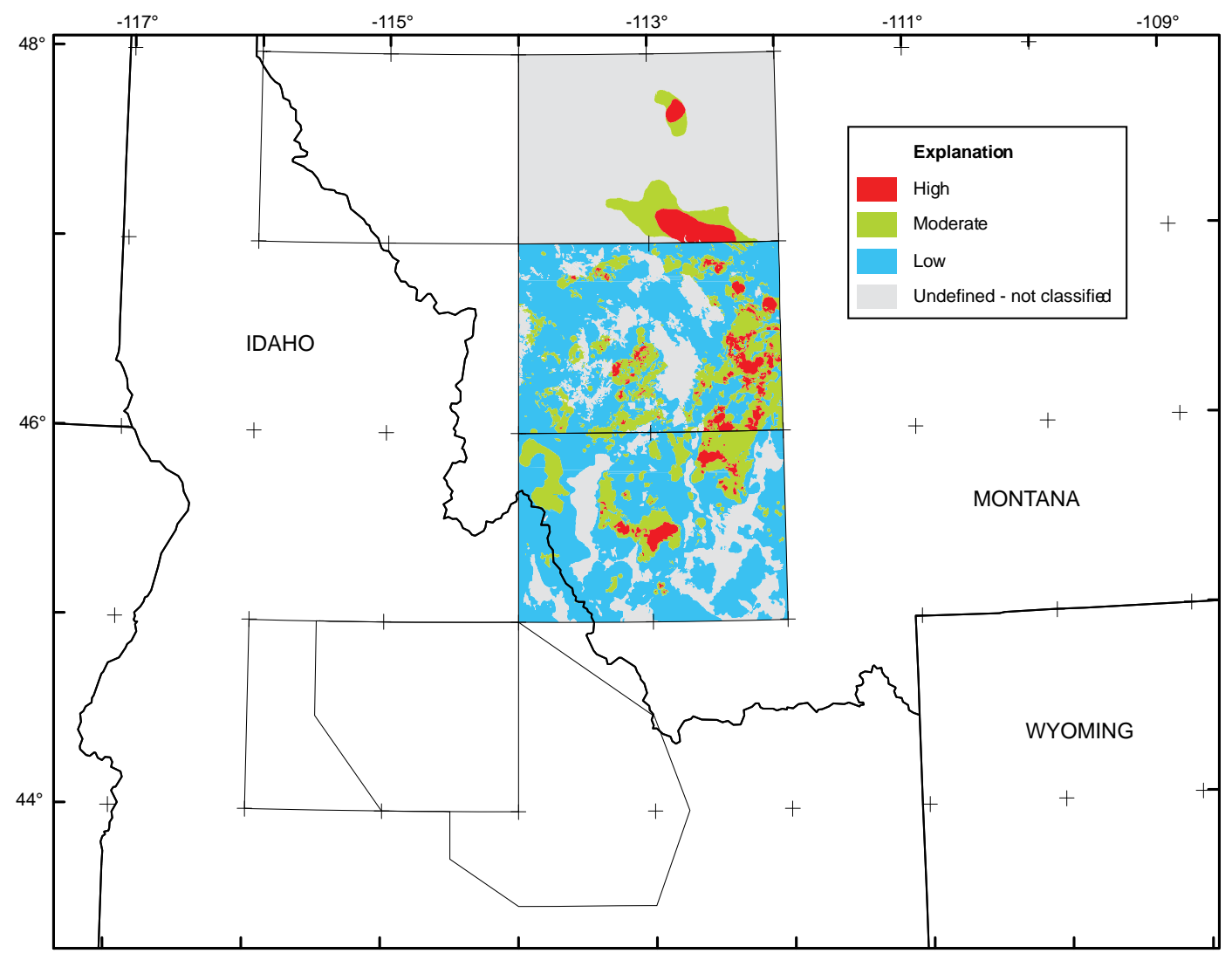

Figure 4. Sketch map of the study area, showing areas identified in USGS $1^{\circ} \times 2^{\circ}$ quadrangle assessments in Idaho and Montana that have potential for undiscovered porphyry copper-style mineralization. 


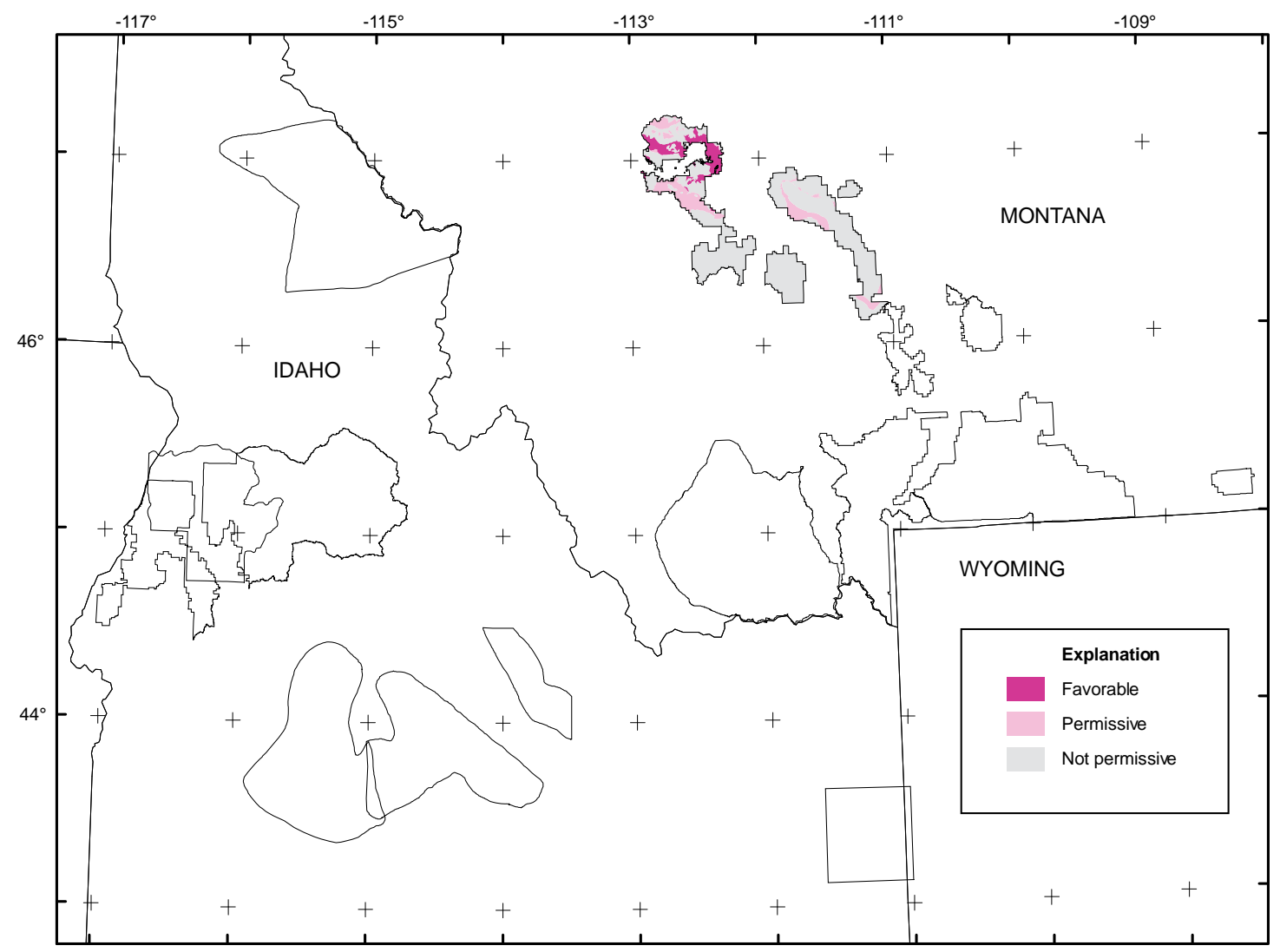

Figure 5. Sketch map of the study area, showing areas identified in USGS assessments of USFS National Forests in Idaho and Montana that are permissive and favorable for undiscovered sediment-hosted copper-style mineralization. 


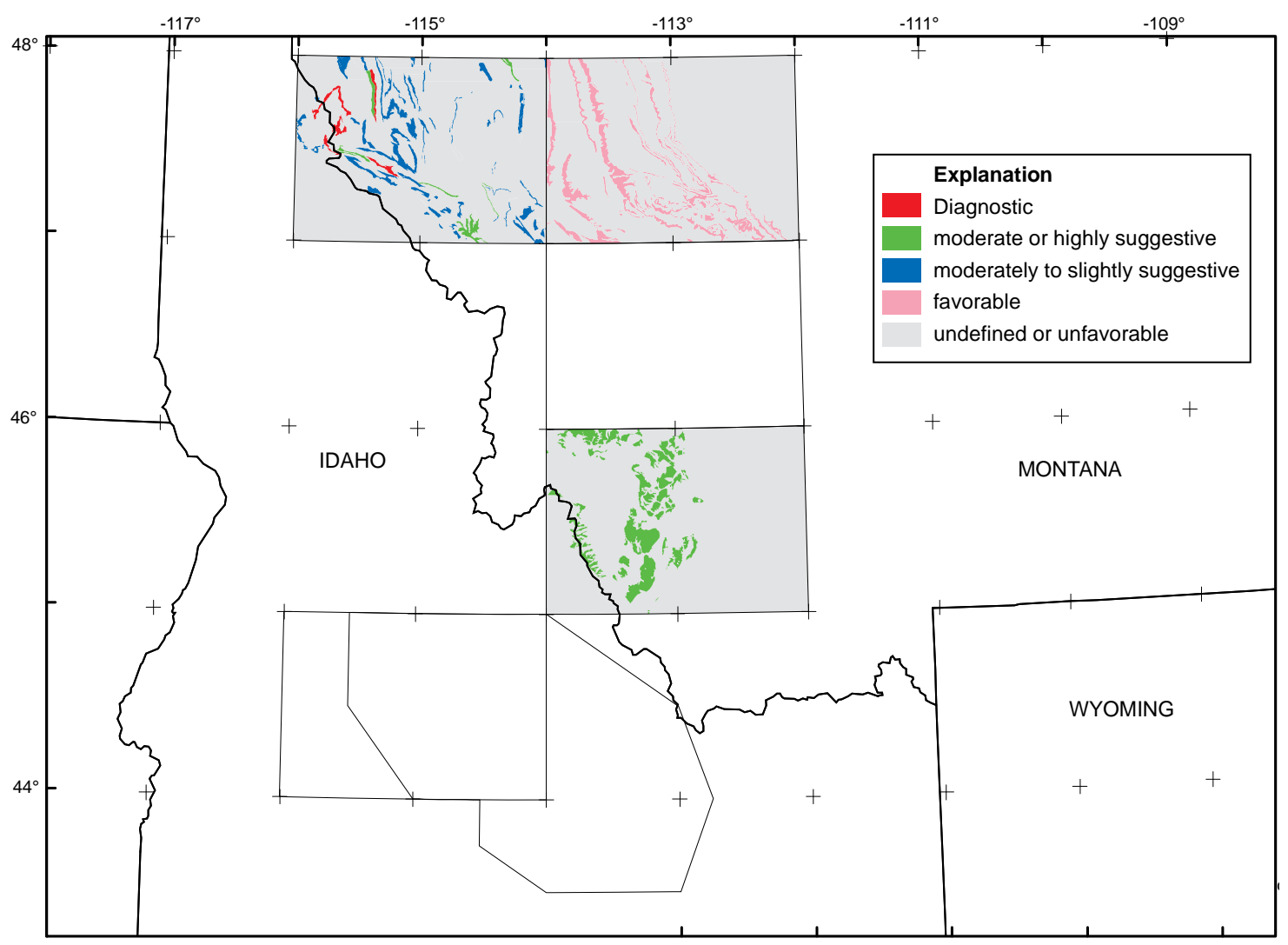

Figure 6. Sketch map of the study area, showing areas identified in USGS $1^{\circ} \times 2^{\circ}$ quadrangle assessments in Idaho and Montana that have potential for undiscovered sediment-hosted copper-style mineralization. 


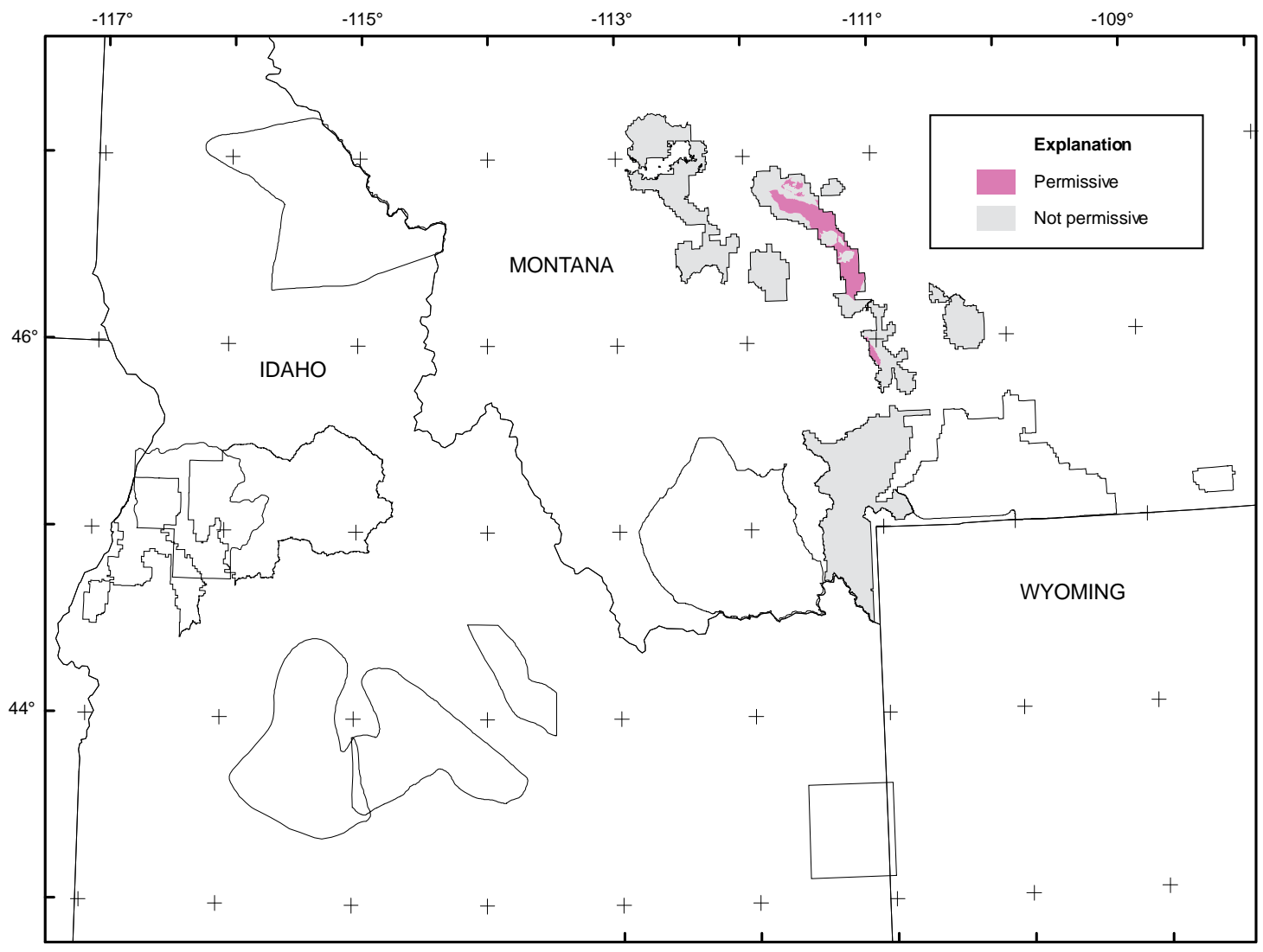

Figure 7. Sketch map of the study area, showing areas identified in USGS assessments of USFS National Forests in Idaho and Montana that are permissive and favorable for undiscovered sedimentary exhalative lead-zinc-style mineralization. 


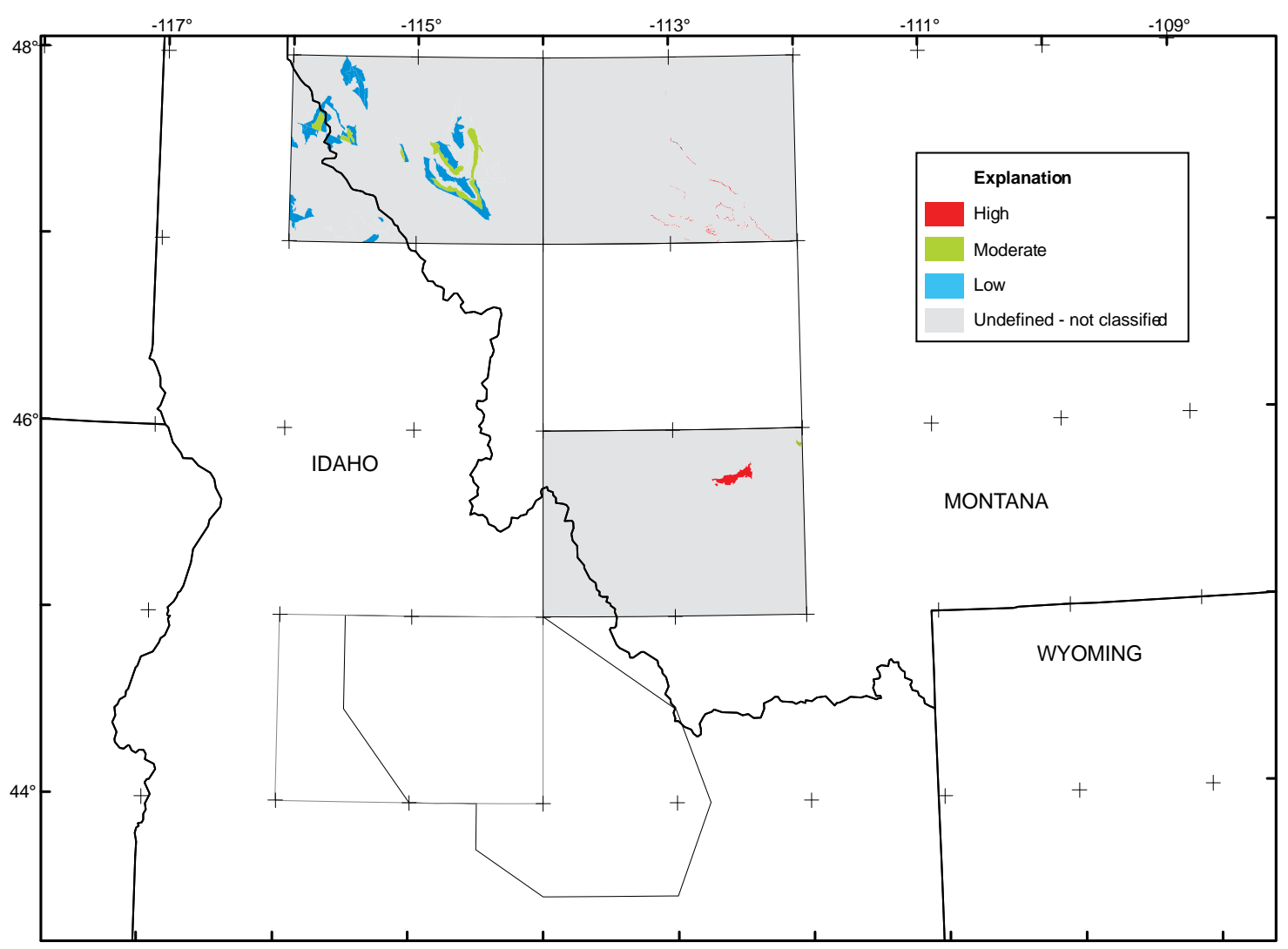

Figure 8. Sketch map of the study area, showing areas identified in USGS $1^{\circ} \times 2^{\circ}$ quadrangle assessments in Idaho and Montana that have potential for undiscovered sedimentary exhalative lead-zinc-style mineralization.

Inconsistencies in the name of mineral deposit types and models may confuse some users, although the terminology will be familiar to geologists with a background in economic geology. All users will benefit by referring to published descriptions of mineral deposit models, both those included in the original reports as well as separate compilations (such as Cox and Singer, 1986). Stoesser and Heran (2000) assembled many mineral deposit models published by the USGS into a single report.

The USGS subsequently published regional assessments that include Idaho and Montana, including a national mineral resource assessment (U.S. Geological Survey National Mineral Resource Assessment Team, 2000) and an assessment conducted for the Interior Columbia Basin Ecosystem Management Project (Box and others, 1996). Spatial databases are available for both of these datasets; however, these studies considered a limited number of commodities and had to generalize information due to the scale of the assessment (approximately 1:1,000,000). These regional assessments provide an important overview; however, the scale of the assessments included in this report are better suited to regional planning, consider more deposit types, and provide more in-depth analysis. Boleneus and others (2005) published an assessment of sediment-hosted copper mineralization in the Revett Formation in northern Idaho and northwestern Montana; spatial datasets are available in that report. 


\section{References Cited}

Boleneus, D.E., Appelgate, L.M., Stewart, J.H., and Zientek, M.L., 2005, Stratabound copper-silver deposits of the Mesoproterozoic Revett Formation, Montana and Idaho, with a section on databases and spatial-data files for the geology and mineral deposits of the Revett Formation by Boleneus, David E., Appelgate, Larry M., Carlson, Mary H., Chase, Derrick, W., and Zientek, Michael L.: U.S. Geological Survey Scientific Investigations Report 2005-5231, 66 p. [URL http://pubs.usgs.gov/sir/2005/5231/].

Bookstrom, A.A., Johnson, B.R., Cookro, T.M., Lund, K., Watts, K.C., King, H.D., Kleinkopf, M.D., Pitkin, J.A., Sanchez, J.D., and Causey, J.D., 1998, Potential mineral resources, Payette National Forest, Idaho: Description and probabilistic estimation: U.S. Geological Survey Open-File Report 98-219a, 180 p., 1 sheet, scale 1:100,000 [URL http://pubs.er.usgs.gov/usgspubs/ofr/ofr98219A/].

Box, S. E., Bookstrom, A. A., Zientek, M. L., Derkey, P. D., Ashley, R. P., Elliott, J. E., and Peters, S. G., 1996, Assessment of undiscovered mineral resources in the Pacific Northwest: A contribution to the Interior Columbia Basin Ecosystem Management Project: U.S. Geological Survey Open-File Report 95682, 415 p. [URL http://pubs.er.usgs.gov/usgspubs/ofr/ofr95682/].

Causey, J.D., 2005, Mining claim activity on Federal land for the period 1976 through 2003: U.S. Geological Survey Data Series 124, 27 p. [URL http://pubs.usgs.gov/ds/124/].

Cox, D.P. and Singer, D.A., eds., 1986, Mineral Deposit Models: U.S. Geological Survey Bulletin 1693, 379 p. [URL http://pubs.usgs.gov/bul/b1693/].

Earhart, R.L., Grimes, D.L., Leinz, R.W., and Kleinkopf, M.D., 1981a, The Conterminous United States Mineral Appraisal Program: Background information to accompany folio of geologic, geochemical, geophysical, and mineral resource maps of the Choteau $1^{\circ}$ x $2^{\circ}$ quadrangle, Montana: U.S. Geological Survey Circular 849, 9 p. [URL http://pubs.er.usgs.gov/usgspubs/cir/cir849/].

Earhart, R.L., Mudge, M.R., Whipple, J.W., and Connor, J.J., 1981b, Mineral resources of the Choteau $1^{\circ}$ x $2^{\circ}$ quadrangle, Montana: U.S. Geological Survey Miscellaneous Field Studies Map MF 858A, 1 sheet, scale 1:250,000.

Elliott, J.E., Trautwein, C.M., Wallace, C.A., Lee, G.K., Rowan, L.C., and Hanna, W.F., 1993a, The Conterminous United States Mineral Appraisal Program: Background information to accompany folio of geologic, geochemical, remote sensing, and mineral resource maps of the Butte $1^{\circ} \times 2^{\circ}$ degree quadrangle, Montana: U.S. Geological Survey Circular 1088, 17 p. [URL http://pubs.er.usgs.gov/usgspubs/cir/cir1088/].

Elliott, J.E., Wallace, C.A., Lee, G.K., Antweiler, J.C., Lidke, D.J., Rowan, L.C., Hanna, W.F., Trautwein, C.M., Dwyer, J.L., and Moll, S.H., 1992a, Maps showing mineral resource assessment for skarn deposits of gold, silver, copper, tungsten and iron in the Butte $1^{\circ} \times 2^{\circ}$ quadrangle, Montana: U.S. Geological Survey Miscellaneous Investigations Series Map I-2050-E, 2 sheets, scale 1:250,000 [URL http://pubs.er.usgs.gov/usgspubs/i/i2050E/].

Elliott, J.E., Wallace, C.A., Lee, G.K., Antweiler, J.C., Lidke, D.J., Rowan, L.C., Hanna, W.F., Trautwein, C.M., Dwyer, J.L., and Moll, S.H., 1992b, Maps showing mineral resource assessment for vein and replacement deposits of gold, silver, copper, lead, zinc, manganese, and tungsten in the Butte $1^{\circ} \mathrm{x} 2^{\circ}$ degree quadrangle, Montana: U.S. Geological Survey Miscellaneous Investigations Series Map I-2050D, 1 sheet, scale 1:250,000 [URL http://pubs.er.usgs.gov/usgspubs/i/i2050D/].

Elliott, J.E., Wallace, C.A., Lee, G.K., Antweiler, J.C., Lidke, D.J., Rowan, L.C., Hanna, W.F., Trautwein, C.M., Dwyer, J.L., and Moll, S.H., 1993b, Maps showing mineral resource assessment for porphyry and stockwork deposits of copper, molybdenum and tungsten and for stockwork and disseminated deposits of gold and silver in the Butte $1^{\circ}$ x $2^{\circ}$ degree quadrangle, Montana: U.S. Geological Survey

Miscellaneous Investigations Series Map I-2050-F, 3 sheets, scale 1:250,000 [URL http://pubs.er.usgs.gov/usgspubs/i/i2050F/]. 
Fisher, F.S. and Johnson, K.M., 1995, Geology and mineral resource assessment of the Challis $1^{\circ} \mathrm{x} 2^{\circ}$ degree quadrangle, Idaho: U.S. Geological Survey Professional Paper 1525, 201 p., 23 sheets, scale 1:250,000 [URL http://pubs.er.usgs.gov/usgspubs/pp/pp1525/].

Goudarzi, G.H., compiler, 1984, Guide to preparation of mineral survey reports on public lands: U.S. Geological Survey Open-File Report 84-787, 38 p. [URL http://pubs.er.usgs.gov/usgspubs/ofr/ofr84787/].

Green, G.N. and Tysdal, R.G., 1996, Digital maps and figures on CD-ROM for mineral and energy resource assessment of the Helena National Forest, west-central Montana: U.S. Geological Survey Open-File Report 96-683-B, 16 sheets, scale 1:126,720.

Hammarstrom, J.M., Van Gosen, B.S., Carlson, R.R., and Kulik, D.M., 1999, Map showing areas with potential for mineral deposits in Precambrian mafic and ultramafic rocks in the Blacktail and Henrys Lake Mountains and the Greenhorn and Ruby Ranges of southwestern Montana: U.S. Geological Survey Open-File Report 98-224d, scale 1:250,000 [URL http://pubs.usgs.gov/of/1998/ofr-98-0224d/98-224d.pdf].

Hammarstrom, J.M., Zientek, M.L., and Elliott, J.E., 1993, Mineral resource assessment of the AbsarokaBeartooth study area, Custer and Gallatin National Forests, Montana: U.S. Geological Survey Open-File Report 93-207, 19 sheets, scale 1:126,720 [URL http://pubs.er.usgs.gov/usgspubs/ofr/ofr93207/].

Harrison, J.E., Cressman, E.R., Long, C.L., Leach, D.L., and Domenico, J.A., 1986, Resource appraisal map for Sullivan-type stratabound lead-zinc-silver deposits in the Wallace $1^{\circ} \mathrm{x} 2^{\circ}$ quadrangle, Montana and Idaho: U.S. Geological Survey Miscellaneous Investigations Series Map I-1509-G, 1 sheet, scale 1:250,000 [URL http://pubs.er.usgs.gov/usgspubs/i/i1509G/].

Harrison, J.E., Domenico, J.A., and Leach, D.L., 1986a, Resource appraisal map for placer gold in the Wallace $1^{\circ}$ x $2^{\circ}$ quadrangle, Montana and Idaho: U.S. Geological Survey Miscellaneous Investigations Series Map I-1509-E, 1 sheet, scale 1:250,000 [URL http://pubs.er.usgs.gov/usgspubs/i/i1509E/].

Harrison, J.E., Domenico, J.A., and Leach, D.L., 1986b, Resource appraisal map for stratabound coppersilver deposits in the Wallace $1^{\circ}$ x $2^{\circ}$ quadrangle, Montana and Idaho: U.S. Geological Survey Miscellaneous Investigations Series Map I-1509-F, 1 sheet, scale 1:250,000 [URL http://pubs.er.usgs.gov/usgspubs/i/i1509F/].

Harrison, J.E., Leach, D.L., and Kleinkopf, M.D., 1986a, Resource appraisal maps for mesothermal baseand precious-metal veins in the Wallace $1^{\circ}$ x $2^{\circ}$ quadrangle, Montana and Idaho: U.S. Geological Survey Miscellaneous Investigations Series Map I-1509-I, 2 sheets, scale 1:250,000.

Harrison, J.E., Leach, D.L., Kleinkopf, M.D., and Long, C.L., 1986b, Resource appraisal map for porphyry molybdenum-tungsten, platinum-group metals and epithermal silver deposits in the Wallace $1^{\circ}$ x $2^{\circ}$ quadrangle, Montana and Idaho: U.S. Geological Survey Miscellaneous Investigations Series Map I-1509-H, 1 sheet, scale 1:250,000 [URL http://pubs.er.usgs.gov/usgspubs/i/i1509H/].

Harrison, J.E., Leach, D.L., Kleinkopf, M.D., Long, C.L., Rowan, L.C., and Marvin, R.F., 1986c, The Conterminous United States Mineral Appraisal Program: Background information to accompany folio of geologic, geochemical, geophysical, remote sensing, and mineral resource maps of the Wallace $1^{\circ} \mathrm{x}$ $2^{\circ}$ quadrangle, Montana and Idaho: U.S. Geological Survey Circular 920, 13 p. [URL http://pubs.er.usgs.gov/usgspubs/cir/cir920/].

Johnson, K.M. and Worl, R.G., 1991, Mineral resource studies of National Forest roadless areas in Idaho: U.S. Geological Survey Open-File Report 91-589, 84 p., scale 1:100,000 [URL http://pubs.er.usgs.gov/usgspubs/ofr/ofr91589/].

Klein, T.L., 2004, Mineral deposit data for epigenetic base- and precious-metal and uranium-thorium deposits in south-central and southwestern Montana and southern and central Idaho: U.S. Geological Survey Open-File Report 2004-1005, 16 p. [URL http://pubs.usgs.gov/of/2004/1005/].

Kropschot, S.J., 2006, USGS Mineral Resources Program - Supporting stewardship of America's natural resources: U.S. Geological Survey Circular 1289, 35 p. [URL http://pubs.usgs.gov/circ/2006/1289/]. 
Larsen, J.C., Assmus, K.C., Causey, J.D., and Zientek, M.L., 2004, Rectified images of selected geologic maps in the northern Rockies area, Idaho, Montana, Washington, and Wyoming: U.S. Geological Survey Data Series 106, 17 p. [URL http://pubs.usgs.gov/ds/106/].

Pearson, R.C., Hanna, W.F., James, H.L., Loen, J.S., Moll, S.H., Ruppell, E.T., and Trautwein, C.M., 1990, Map showing mineral resource assessment for Ag, Co, and base metals in Proterozoic sedimentary rocks and for $\mathrm{Fe}, \mathrm{Cr}, \mathrm{Ni}$, talc, chlorite, $\mathrm{Au}$, and graphite in Archean crystalline rocks, Dillon $1^{\circ}$ x $2^{\circ}$ quadrangle, Idaho and Montana: U.S. Geological Survey Miscellaneous Investigations Series Map I-1803-D, 1 sheet, scale 1:250,000.

Pearson, R.C., Loen, J.S., Trautwein, Ruppel, E.T., and Moll, S.H., 1991, Maps showing mineral resource assessment for placer gold and silver, Dillon $1^{\circ}$ x $2^{\circ}$ quadrangle, Idaho and Montana: U.S. Geological Survey Miscellaneous Investigations Series Map I-1803-F, 1 sheet, scale 1:250,000.

Pearson, R.C., Trautwein, C.M., Berger, B.R., Hanna, W.F., Jenson, S.K., Loen, J.S., Moll, S.H., Purdy, T.L., Rowan, L.C., Ruppel, E.T., and Segal, D.B., 1992a, Maps showing mineral resource assessment for vein and replacement deposits of base and precious metals, barite, and fluorspar, Dillon $1^{\circ} \times 2^{\circ}$ quadrangle, Idaho and Montana: U.S. Geological Survey Miscellaneous Investigations Series Map I1803-E, 2 sheets, scale 1:250,000 [URL http://pubs.er.usgs.gov/usgspubs/i/i1803E/].

Pearson, R.C., Trautwein, C.M., Moll, S.H., Berger, B.R., Hanna, W.F., Loen, J.S., Rowan, L.C., Ruppel, E.T., and Segal, D.B., 1992b, Maps showing mineral resource assessment for copper and molybdenum in porphyry and stockwork deposits and for tungsten, iron, gold, copper, and silver in skarn deposits, Dillon $1^{\circ}$ x $2^{\circ}$ quadrangle, Idaho and Montana: U.S. Geological Survey Miscellaneous Investigations Series Map I-1803-G, 3 sheets, scale 1:250,000.

Pearson, R.C., Trautwein, C.M., Ruppel, E.T., Hanna, W.F., Rowan, L.C., Loen, J.S., and Berger, B.R., 1992c, Mineral resource assessment of the Dillon $1^{\circ}$ x $2^{\circ}$ quadrangle, Idaho and Montana: U.S. Geological Survey Circular 1077, 15 p.

Pratt, W.P., 1981, Metallic mineral-resource potential of the Rolla $1^{\circ} \times 2^{\circ}$ quadrangle, Missouri, as appraised in September 1980: U.S. Geological Survey Open-File Report 81-518, 82 p., 3 oversize sheets, scale 1:250,000 [URL http://pubs.er.usgs.gov/usgspubs/ofr/ofr81518/].

Root, D.H., Menzie, W.G., and Scott, W.A., 1992, Computer Monte Carlo simulation in quantitative resource estimation: Nonrenewable Resources, v. 1, p. 125-138.

Selner, G.I, and Taylor, R.B., 1993, System 9. GSMAP, and other programs for the IBM PC and compatible microcomputers, to assist workers in the earth sciences: U.S. Geological Survey Open-File Report 93-511, 372 p. plus 2 micro disks [URL http://pubs.usgs.gov/of/1993/ofr-93-0511/].

Shawe, D.R., 1981, U.S. Geological Survey workshop on nonfuel mineral-resource appraisal of Wilderness and CUSMAP areas: U.S. Geological Survey Circular 845, 18 p. [URL http://pubs.er.usgs.gov/usgspubs/cir/cir845/].

Singer, D.A., 1993, Basic concepts in three-part quantitative assessments of undiscovered mineral resources: Nonrenewable Resources, v. 2, p. 69-81.

Spanski, G.T., 2001, Inventory of mines and mining-related facilities in Idaho and western Montana active from 1997 through 2000: U.S. Geological Survey Open-File Report 01-129, 14 p. [URL http://pubs.usgs.gov/of/2001/ofr-01-0129/].

Spanski, G.T., 2004, Inventory of significant mineral deposit occurrences in the Headwaters project area in Idaho, western Montana, and extreme eastern Oregon and Washington: U.S. Geological Survey Open-File Report 2004-1038, 13 p. [URL http://pubs.usgs.gov/of/2004/1038/].

Stoeser, D.B. and Heran, W.D., 2000, USGS mineral deposit models: U.S. Geological Survey Digital Data Series 064. CD-ROM.

Taylor, R.B., and Steven, T.A., 1983, Definition of mineral resource potential: Economic Geology, v. 78, p. 1268-1270.

Tysdal, R.G., Ludington, Steve, and McCafferty, A.E., 1996, Mineral and energy assessment of the Helena National Forest, west-central Montana: U.S. Geological Survey Open-File Report 96-683-A, 321 p., 18 maps on 6 sheets, scale 1:126,720 [URL http://pubs.er.usgs.gov/usgspubs/ofr/ofr96683A/]. 
U.S. Geological Survey National Mineral Resource Assessment Team, 2000, 1998 assessment of undiscovered deposits of gold, silver, copper, lead, and zinc in the United States: U.S. Geological Survey Circular 1178, 21 pages and CD-ROM [URL http://pubs.er.usgs.gov/usgspubs/cir/cir1178/].

Van Gosen, B.S., Berg, R.B., and Hammarstrom, J.M., 1998a, Map showing areas with potential for talc deposits in the Gravelly, Greenhorn, and Ruby Ranges and the Henrys Lake Mountains of southwestern Montana: U.S. Geological Survey Open-File Report 98-224-B, scale 1:250,000 [URL http://pubs.usgs.gov/of/1998/ofr-98-0224-b/98_224b.pdf].

Van Gosen, B.S., Hammarstrom, J.M., Kellogg, K.S., and Berg, R.B., 1998b, Map showing areas with potential for garnet resources in bedrock and placer in the Blacktail Mountains and the Gravelly, Greenhorn, Ruby, and Snowcrest Ranges of southwestern Montana: U.S. Geological Survey Open-File Report 98-224-A, scale 1:250,000 [URL http://pubs.usgs.gov/of/1998/ofr-98-0224-a/98_224a.pdf].

Van Gosen, B.S., Wilson, A.B., and Hammarstrom, J.M., 1996, Mineral resource assessment of the Custer National Forest in the Pryor Mountains, Carbon County, south-central Montana: U.S. Geological Survey Open-File Report 96-256, 80 p., scale 1:126,720 [URL http://pubs.er.usgs.gov/usgspubs/ofr/ofr96256/].

Wilson, A.B., Hammarstrom, J.M., and Van Gosen, B.S., eds., 2005, Mineral and energy resource assessment of the Gallatin National Forest (exclusive of the Absaroka-Beartooth study area) in Gallatin, Madison, Meagher, Park, and Sweet Grass Counties, south-central Montana: U.S. Geological Survey Professional Paper 1654, scale 1:126,720 [URL http://pubs.usgs.gov/pp/2005/1654/].

Worl, R.G., Burack-Wilson, A., Smith, C.L., and Kleinkopf, M.D., 1989, Mineral resource potential and geology of the Challis National Forest, Idaho: U.S. Geological Survey Bulletin 1873, 101 p., 4 sheets, scale 1:250,000 [URL http://pubs.er.usgs.gov/usgspubs/b/b1873/].

Zientek, M.L., Derkey, P.D., Miller, R.J., Causey, J.D., Bookstrom, A.A., Carlson, M.H., Green, G.N., Frost, T.P., Boleneus, D.E., Evans, K.V., Van Gosen, B.S., Wilson, A.B., Larsen, J.C., Kayser, H.Z., Kelley, W.N., and Assmus, K.C., 2005, Spatial databases for the geology of the Northern Rocky Mountains - Idaho, Montana, and Washington: U.S. Geological Survey Open-File Report 2005-1235, 206 p. [URL http://pubs.usgs.gov/of/2005/1235/].

Zientek, M.L., and Kropschot, S.J., 2005, Mineral resources research supports land-use planning in the Northern Rocky Mountains: U.S. Geological Survey Fact Sheet 2005-3155, 2 p. [URL http://pubs.usgs.gov/fs/2005/3155/]. 


\section{Appendix A. List of Arclnfo datasets representing areas of mineral potential from CUSMAP and National Forest mineral resource assessments in Idaho and}

\section{Montana.}

\begin{tabular}{|c|c|c|c|c|}
\hline Arclnfo interchange-format file name & Deposit type assessed & Source material & $\begin{array}{c}\text { The overall } \\
\text { horizontal } \\
\text { accuracy (+/-) of } \\
\text { the spatial digital } \\
\text { databases, in } \\
\text { meters }\end{array}$ & Reference \\
\hline \multicolumn{5}{|c|}{ Three-part form mineral resource assessments } \\
\hline \multicolumn{5}{|c|}{ Absaroka-Beartooth study area, Custer and Gallatin National Forests, Montana, scale 1:126,720 } \\
\hline aba_dvnsg.e00 & polymetallic veins & $\begin{array}{l}\text { Unpublished GSMAP files were converted } \\
\text { to ArcInfo datasets. }\end{array}$ & 380 & $\begin{array}{l}\text { Hammarstrom and } \\
\text { others (1993) }\end{array}$ \\
\hline abalkpgeg.e00 & $\begin{array}{l}\text { alkaline gabbro-syenite-hosted } \\
\text { copper-gold-PGE deposits }\end{array}$ & do & 444 & do \\
\hline abalsufeg.e00 & Algoma/Superior iron & do & 317 & do \\
\hline abauagtg.e00 & gold-silver-tellurium veins & do & 272 & do \\
\hline abausknsg.e00 & gold-bearing skarn & do & 253 & do \\
\hline abbcevnsg.e00 & polymetallic veins & do & 272 & do \\
\hline abbuscrg.e00 & Bushveld chromite deposits & do & 190 & do \\
\hline abdispgeg.e00 & discordant PGE & do & 190 & do \\
\hline abepivng.e00 & epithermal vein & do & 253 & do \\
\hline ablodeaug.e00 & Homestake $\mathrm{Au}$ & do & 222 & do \\
\hline abmrpgeg.e00 & $\begin{array}{l}\text { Merensky Reef platinum-group } \\
\text { elements (PGE) }\end{array}$ & do & 127 & do \\
\hline abpegmatg.e 00 & pegmatite deposits & do & 222 & do \\
\hline abplacaug.e00 & placer gold deposits & do & 158 & do \\
\hline abporcug.e00 & porphyry copper & do & 253 & do \\
\hline abpppgeg.e00 & Picket Pin PGE & do & 127 & do \\
\hline abredcrg.e00 & Red Lodge chromite & do & 190 & do \\
\hline abserpasg.e00 & serpentine-hosted asbestos & do & 190 & do \\
\hline abstnicug.e00 & Stillwater nickel-copper & do & 127 & do \\
\hline abstracrg.e00 & $\begin{array}{l}\text { PGE-enriched stratiform } \\
\text { chromitite }\end{array}$ & do & 127 & do \\
\hline aburang.e00 & uranium deposits & do & 190 & do \\
\hline
\end{tabular}




\begin{tabular}{|c|c|c|c|c|}
\hline Arclnfo interchange-format file name & Deposit type assessed & Source material & $\begin{array}{c}\text { The overall } \\
\text { horizontal } \\
\text { accuracy (+/-) of } \\
\text { the spatial digital } \\
\text { databases, in } \\
\text { meters }\end{array}$ & Reference \\
\hline \multicolumn{5}{|c|}{ Dillon BLM Resource Area, scale 1:250,000 } \\
\hline drabdrgtg.e00 & bedrock garnet & Unpublished ArcInfo datasets. & 950 & $\begin{array}{l}\text { Van Gosen and } \\
\text { others (1998b) }\end{array}$ \\
\hline dragarplg.e00 & garnet placer & do & 1014 & do \\
\hline dratalcg.e00 & talc deposits & do & 1267 & $\begin{array}{l}\text { Van Gosen and } \\
\text { others (1998a) }\end{array}$ \\
\hline draulmafg.e00 & mafic or ultramafic rock & do & 800 & $\begin{array}{l}\text { Hammarstrom and } \\
\text { others (1999) }\end{array}$ \\
\hline \multicolumn{5}{|c|}{ Gallatin National Forest (exclusive of the Absaroka-Beartooth study area), scale 1:126,720 } \\
\hline galalksyg.e00 & $\begin{array}{l}\text { alkaline gabbro-syenite hosted } \\
\text { copper-gold-PGE deposits }\end{array}$ & Unpublished ArcInfo datasets. & 507 & $\begin{array}{l}\text { Wilson and others } \\
(2005)\end{array}$ \\
\hline galauagtg.e00 & gold-silver-telluride vein & do & 760 & do \\
\hline galauskng.e00 & gold-bearing skarn & do & 2028 & do \\
\hline galchromg.e00 & mafic/ultramafic-hosted chromite & do & 1690 & do \\
\hline galcorung.e $00 \mathrm{~g}$ & corundum-sillimanite deposits & do & 1690 & do \\
\hline galepivng.e00 & epithermal vein deposits & do & 2028 & do \\
\hline galnicug.e00 & magmatic $\mathrm{Ni}, \mathrm{Cu}, \mathrm{PGE}$ deposits & do & 1690 & do \\
\hline galpegmag.e00 & pegmatite deposits & do & 1690 & do \\
\hline galphospg.e00 & $\begin{array}{l}\text { upwelling-type phosphate } \\
\text { deposits }\end{array}$ & do & 2028 & do \\
\hline galpmvbmg.e00 & polymetallic replacement & do & 2028 & do \\
\hline galpmvg.e00 & polymetallic veins & do & 2534 & do \\
\hline galporcug.e00 & porphyry copper & do & 2028 & do \\
\hline galserpag.e00 & serpentine-hosted asbestos & do & 1690 & do \\
\hline galtaleqg.e00 & $\begin{array}{l}\text { talc associated with dolomitic } \\
\text { rocks }\end{array}$ & do & 1690 & do \\
\hline galtalshg.e00 & $\begin{array}{l}\text { talc associated with ultramafic } \\
\text { rocks }\end{array}$ & do & 1690 & do \\
\hline galvermg.e00 & vermiculite deposits & do & 2028 & do \\
\hline galxznpbg.e00 & $\begin{array}{l}\text { sedimentary exhalative zinc-lead } \\
\text { deposits }\end{array}$ & do & 760 & do \\
\hline \multicolumn{5}{|c|}{ Helena National Forest, scale 1:126,720 } \\
\hline hnfauplag.e00 & placer gold & Published ArcInfo datasets. & 750 & $\begin{array}{l}\text { Tysdal and others } \\
\text { (1996); Green and }\end{array}$ \\
\hline
\end{tabular}




\begin{tabular}{|c|c|c|c|c|}
\hline Arclnfo interchange-format file name & Deposit type assessed & Source material & $\begin{array}{l}\text { The overall } \\
\text { horizontal } \\
\text { accuracy (+/-) of } \\
\text { the spatial digital } \\
\text { databases, in } \\
\text { meters }\end{array}$ & Reference \\
\hline & & & & Tysdal (1996) \\
\hline hnfauskng.e00 & gold skarn & do & 62.5 & do \\
\hline hnfauvnsg.e00 & Cretaceous gold-bearing vein & do & 250 & do \\
\hline hnfclimog.e00 & Climax molybdenum & do & 438 & do \\
\hline hnfexhaug.e00 & $\begin{array}{l}\text { York-type exhalative (?) gold } \\
\text { deposits }\end{array}$ & do & 125 & do \\
\hline hnfeznpbg.e00 & $\begin{array}{l}\text { sedimentary exhalative zinc-lead } \\
\text { deposits }\end{array}$ & do & 275 & do \\
\hline hnfgoldg.e00 & gold deposits & do & 375 & do \\
\hline hnfhagaug.e00 & hot-spring gold-silver & do & 438 & do \\
\hline hnflimdog.e00 & limestone and dolomite & $\begin{array}{l}\text { Polygons with the label attribute = 'Kk, } \\
\text { Kju, Ju, PPMu, PPq, Pma, Ysh, Yh, Yn, } \\
\text { Mm, MDCu, Mdu, Cu, Crh, Cmu, Cmw' } \\
\text { in the geology coverage (Tysdal and others, } \\
\text { 1996; Green and Tysdal, 1996) were } \\
\text { selected to represent the hnflimdog dataset. }\end{array}$ & 438 & do \\
\hline hnfpmrplg.e00 & polymetallic replacement & Published ArcInfo datasets. & 438 & do \\
\hline hnfpolvng.e00 & polymetallic vein & do & 375 & do \\
\hline hnfporcug.e00 & porphyry copper & do & 313 & do \\
\hline hnfquadug.e00 & epithermal vein, quartz adularia & do & 250 & do \\
\hline hnfredcug.e00 & $\begin{array}{l}\text { sediment-hosted copper, redbed } \\
\text { type }\end{array}$ & do & 250 & do \\
\hline hnfwskrng.e00 & tungsten- (molybdenum) skarn & do & 125 & do \\
\hline \multicolumn{5}{|c|}{ National Forest Roadless Areas in Idaho, scale 1:100,000 } \\
\hline id1clfmog.e00 & $\begin{array}{l}\text { Cretaceous low-fluorine } \\
\text { porphyry molybdenum deposits }\end{array}$ & $\begin{array}{l}\text { Unpublished GSMAP files were converted } \\
\text { to ArcInfo datasets. }\end{array}$ & 697 & $\begin{array}{l}\text { Johnson and Worl } \\
\text { (1991) }\end{array}$ \\
\hline id1ctevg.e00 & Comstock epithermal vein & do & 634 & do \\
\hline id1pqvnlg.e00 & $\begin{array}{l}\text { polymetallic quartz vein and lode } \\
\text { (mixed base- and precious metal } \\
\text { veins) }\end{array}$ & do & 1267 & do \\
\hline id1rbsdpg.e00 & radioactive black sand placers & do & 634 & do \\
\hline id1tlfmog.e00 & $\begin{array}{l}\text { Tertiary low-fluorine porphyry } \\
\text { molybdenum deposits }\end{array}$ & do & 697 & do \\
\hline id2clfmog.e00 & $\begin{array}{l}\text { Cretaceous low-fluorine } \\
\text { porphyry molybdenum }\end{array}$ & do & 845 & do \\
\hline
\end{tabular}




\begin{tabular}{|c|c|c|c|c|}
\hline Arclnfo interchange-format file name & Deposit type assessed & Source material & $\begin{array}{c}\text { The overall } \\
\text { horizontal } \\
\text { accuracy (+/-) of } \\
\text { the spatial digital } \\
\text { databases, in } \\
\text { meters }\end{array}$ & Reference \\
\hline id2ctevng.e00 & Comstock epithermal veins & do & 1478 & do \\
\hline id2polvng.e00 & polymetallic veins & do & 634 & do \\
\hline id2pqvnlg.e00 & $\begin{array}{l}\text { polymetallic quartz vein and lode } \\
\text { (mixed base- and precious metal } \\
\text { veins) }\end{array}$ & do & 1267 & do \\
\hline id2tpomog.e00 & $\begin{array}{l}\text { Tertiary low-fluorine porphyry } \\
\text { molybdenum }\end{array}$ & do & 1690 & do \\
\hline id2znpbsg.e00 & $\mathrm{Zn}-\mathrm{Pb}$ skarn deposits & do & 849 & do \\
\hline id3bcocug.e00 & $\begin{array}{l}\text { sediment-hosted (Blackbird-type) } \\
\text { cobalt-copper deposits }\end{array}$ & do & 1267 & do \\
\hline id3losaug.e00 & low-sulfide gold deposits & do & 475 & do \\
\hline id3plaaug.e00 & placer gold & do & 634 & do \\
\hline id3pqvnlg.e00 & $\begin{array}{l}\text { polymetallic quartz vein and lode } \\
\text { (mixed base- and precious metal } \\
\text { veins) }\end{array}$ & do & 697 & do \\
\hline id3rbsdpg.e00 & radioactive black sand placers & do & 1109 & do \\
\hline id3stvolg.e00 & $\begin{array}{l}\text { stratabound volcanogenic } \\
\text { deposits (Kuroko massive } \\
\text { sulfide) }\end{array}$ & do & 634 & do \\
\hline id3wskarg.e00 & tungsten skarn & do & 950 & do \\
\hline id4ctevng.e00 & Comstock epithermal veins & do & 1564 & do \\
\hline id4metkyg.e00 & metamorphic kyanite & do & 1173 & do \\
\hline id4plaaug.e00 & placer gold & do & 978 & do \\
\hline id4polvng.e00 & polymetallic veins & do & 1564 & do \\
\hline id4pqvnlg.e00 & $\begin{array}{l}\text { polymetallic quartz vein and lode } \\
\text { (mixed base- and precious metal } \\
\text { veins) }\end{array}$ & do & 1173 & do \\
\hline id5kphlag.e00 & $\begin{array}{l}\text { upwelling-type phosphate } \\
\text { deposits }\end{array}$ & do & 158 & do \\
\hline \multicolumn{5}{|c|}{ Payette National Forest, scale 1:100,000 } \\
\hline pnfauagvg.e00 & $\begin{array}{l}\text { gold-silver mixed-metal veins } \\
\text { (mixed base- and precious-metal } \\
\text { veins) }\end{array}$ & Published ArcInfo datasets. & 81 & $\begin{array}{l}\text { Bookstrom and } \\
\text { others (1998) }\end{array}$ \\
\hline pnfauskng.e00 & Au-bearing skarn & do & 122 & do \\
\hline pnfbaritg.e00 & barite layers and veins & do & 1584 & do \\
\hline
\end{tabular}




\begin{tabular}{|c|c|c|c|c|}
\hline Arclnfo interchange-format file name & Deposit type assessed & Source material & $\begin{array}{c}\text { The overall } \\
\text { horizontal } \\
\text { accuracy }(+/-) \text { of } \\
\text { the spatial digital } \\
\text { databases, in } \\
\text { meters }\end{array}$ & Reference \\
\hline pnfcuagpg.e00 & copper-silver polymetallic vein & do & 1267 & do \\
\hline pnfdcuagg.e00 & disseminated copper-silver & do & 5069 & do \\
\hline pnfddgsg.e00 & distal disseminated gold-silver & do & 122 & do \\
\hline pnfdissbg.e00 & $\begin{array}{l}\text { disseminated antimony (simple } \\
\text { Sb) deposits }\end{array}$ & do & 122 & do \\
\hline pnfgypsug.e00 & gypsum and anhydrite & do & 4118 & do \\
\hline pnfhsaug.e00 & hot spring gold-silver & do & 609 & do \\
\hline pnfhshgg.e00 & hot spring mercury deposits & do & 0 & do \\
\hline pnfkurokg.e00 & $\begin{array}{l}\text { Kuroko zinc-copper massive } \\
\text { sulfide (Kuroko massive sulfide) }\end{array}$ & do & 1584 & do \\
\hline pnflosaug.e00 & low sulfide Au-quartz veins & do & 1901 & do \\
\hline pnfmmvcug.e00 & copper-gold mixed-metal veins & do & 41 & do \\
\hline pnfmnlvg.e00 & $\begin{array}{l}\text { manganese layer and veins } \\
\text { (Franciscan-type volcanogenic } \\
\text { manganese) }\end{array}$ & do & 5702 & do \\
\hline pnfplyvng.e00 & polymetallic layers and veins & do & 3802 & do \\
\hline pnfporcug.e00 & porphyry copper-molybdenum & do & 3168 & do \\
\hline pnfsbvnsg.e00 & $\begin{array}{l}\text { antimony veins (simple } \mathrm{Sb} \\
\text { deposits) }\end{array}$ & do & 122 & do \\
\hline pnfskncug.e00 & Cu skarn & do & 4118 & do \\
\hline pnfsknfeg.e00 & iron skarn & do & 4118 & do \\
\hline pnfwskarg.e00 & W skarn & do & 406 & do \\
\hline pnfwveing.e00 & $\begin{array}{l}\text { tungsten veins - quartz- } \\
\text { huebnerite (W veins) }\end{array}$ & do & 122 & do \\
\hline pnfznpbsg.e00 & $\mathrm{Zn}-\mathrm{Pb}$ skarn & do & 41 & do \\
\hline \multicolumn{5}{|c|}{ Pryor Mountains, Custer National Forest; scale 1:126,720 } \\
\hline pryhplimg.e00 & high-purity limestone & Unpublished ArcInfo datasets. & 127 & $\begin{array}{l}\text { Van Gosen and } \\
\text { others (1996) }\end{array}$ \\
\hline pryurvang.e00 & $\begin{array}{l}\text { uranium-vanadium (solution- } \\
\text { collapse breccia pipe uranium } \\
\text { deposits) }\end{array}$ & 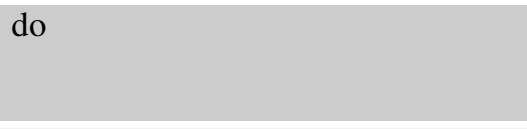 & 127 & do \\
\hline \multicolumn{5}{|c|}{ Non 3-part form mineral resource assessments } \\
\hline \multicolumn{5}{|c|}{ Butte $1^{\circ} \times 2^{\circ}$ quadrangle, scale $1: 250,000$} \\
\hline buporphg.e00 & porphyry/stockwork deposits of & Unpublished raster data files used in & 500 & Elliott and others \\
\hline
\end{tabular}




\begin{tabular}{|c|c|c|c|c|}
\hline Arclnfo interchange-format file name & Deposit type assessed & Source material & $\begin{array}{c}\text { The overall } \\
\text { horizontal } \\
\text { accuracy (+/-) of } \\
\text { the spatial digital } \\
\text { databases, in } \\
\text { meters }\end{array}$ & Reference \\
\hline & $\begin{array}{l}\text { copper, molybdenum, and } \\
\text { tungsten }\end{array}$ & $\begin{array}{l}\text { conducting the CUSMAP assessment were } \\
\text { vectorized to create ArcInfo datasets. }\end{array}$ & & $(1993 b)$ \\
\hline buskarng.e00 & $\begin{array}{l}\text { skarn gold, silver, copper, } \\
\text { tungsten, and iron }\end{array}$ & do & 500 & $\begin{array}{l}\text { Elliott and others } \\
\text { (1992a) }\end{array}$ \\
\hline bustockg.e00 & $\begin{array}{l}\text { stockwork/disseminated deposits } \\
\text { of gold and silver }\end{array}$ & do & 625 & $\begin{array}{l}\text { Elliott and others } \\
\text { (1993b) }\end{array}$ \\
\hline buveing.e00 & $\begin{array}{l}\text { vein deposits of gold, silver, } \\
\text { copper, lead, zinc, tungsten, and } \\
\text { manganese }\end{array}$ & do & 500 & $\begin{array}{l}\text { Elliott and others } \\
\text { (1992b) }\end{array}$ \\
\hline \multicolumn{5}{|c|}{ Challis $1^{\circ} \times 2^{\circ}$ quadrangle, scale $1: 250,000$} \\
\hline ch250argg.e00 & $\begin{array}{l}\text { stratabound syngenetic dep. of } \\
\text { precious and base metals in } \\
\text { argillite and micritic limestone }\end{array}$ & $\begin{array}{l}\text { Selected arcs and polygons were digitized } \\
\text { from paper maps to create ArcInfo datasets. }\end{array}$ & 438 & $\begin{array}{l}\text { Fisher and Johnson } \\
\text { (1995) }\end{array}$ \\
\hline ch250aupg.e00 & gold placer & do & 500 & do \\
\hline ch250bcfg.e00 & $\begin{array}{l}\text { stratabound, stratiform, breccia- } \\
\text { controlled fluorspar deposits in } \\
\text { carbonate rocks }\end{array}$ & do & 250 & do \\
\hline ch250bpmg.e00 & $\begin{array}{l}\text { mixed base- and precious-metal } \\
\text { vein }\end{array}$ & do & 188 & do \\
\hline ch250bspg.e00 & radioactive black sand placer & do & 875 & do \\
\hline ch250cmog.e00 & $\begin{array}{l}\text { Cretaceous molybdenum } \\
\text { stockworks }\end{array}$ & do & 250 & do \\
\hline ch250cog.e00 & $\begin{array}{l}\text { stratabound syngenetic cobalt } \\
\text { copper }\end{array}$ & do & 250 & do \\
\hline ch250epig.e00 & $\begin{array}{l}\text { precious-metal deposits in } \\
\text { epiclastic sediments }\end{array}$ & do & 250 & do \\
\hline ch250fvng.e00 & fluorspar vein & do & 500 & do \\
\hline ch250hgrg.e00 & mercury replacement & do & 250 & do \\
\hline ch250pbvg.e00 & $\begin{array}{l}\text { lead-silver-zinc-antimony-tin } \\
\text { vein }\end{array}$ & do & 250 & do \\
\hline ch250pmvg.e00 & precious-metal vein & do & 500 & do \\
\hline ch250pskg.e00 & polymetallic skarn & do & 375 & do \\
\hline ch250rhyg.e00 & $\begin{array}{l}\text { precious-metal deposits hosted } \\
\text { by high level rhyolites }\end{array}$ & do & 250 & do \\
\hline ch250rplg.e00 & replacement deposits of base and & do & 250 & do \\
\hline
\end{tabular}




\begin{tabular}{|c|c|c|c|c|}
\hline Arclnfo interchange-format file name & Deposit type assessed & Source material & $\begin{array}{c}\text { The overall } \\
\text { horizontal } \\
\text { accuracy (+/-) of } \\
\text { the spatial digital } \\
\text { databases, in } \\
\text { meters }\end{array}$ & Reference \\
\hline & precious metals & & & \\
\hline ch250stug.e00 & $\begin{array}{l}\text { stratiform uranium in } \\
\text { sedimentary rocks }\end{array}$ & do & 500 & do \\
\hline ch250stvg.e00 & stratabound vanadium & do & 500 & do \\
\hline ch250tmog.e00 & $\begin{array}{l}\text { Tertiary molybdenum } \\
\text { stockworks }\end{array}$ & do & 313 & do \\
\hline ch250tufg.e00 & $\begin{array}{l}\text { precious metal deposits in } \\
\text { volcanic tuffs }\end{array}$ & do & 62.5 & do \\
\hline ch250uvng.e00 & uranium vein & do & 250 & do \\
\hline ch250wvrg.e00 & tungsten vein and replacement & do & 250 & do \\
\hline \multicolumn{5}{|c|}{ Challis National Forest, scale 1:250,000 } \\
\hline chnfauplg.e00 & gold placers & $\begin{array}{l}\text { The original published maps were scanned } \\
\text { and vectorized by Optronics Specialty Co., } \\
\text { Inc. to create ArcInfo datasets. }\end{array}$ & 1000 & $\begin{array}{l}\text { Worl and others } \\
\text { (1989) }\end{array}$ \\
\hline chnfbkshg.e00 & $\begin{array}{l}\text { polymetallic veins in black-shale } \\
\text { terrane }\end{array}$ & do & 1000 & do \\
\hline chnfbmvng.e00 & base metal veins & do & 1000 & do \\
\hline chnfbrecg.e00 & fluorspar breccia manto deposits & do & 875 & do \\
\hline chnfcarbg.e00 & $\begin{array}{l}\text { polymetallic veins in carbonate } \\
\text { terrane }\end{array}$ & do & 625 & do \\
\hline chnfflvng.e00 & fluorspar veins & do & 750 & do \\
\hline chnfibpmg.e00 & $\begin{array}{l}\text { irregular replacements of base } \\
\text { and precious metals }\end{array}$ & do & 500 & do \\
\hline chnfjaspg.e00 & $\begin{array}{l}\text { sediment-hosted, jasperoid- } \\
\text { associated, precious-metal } \\
\text { deposits }\end{array}$ & do & 500 & do \\
\hline chnfpmvng.e00 & precious-metal veins & do & 813 & do \\
\hline chnfpskng.e00 & polymetallic skarn deposits & do & 1250 & do \\
\hline chnfquarg.e00 & $\begin{array}{l}\text { polymetallic veins in quartzite } \\
\text { terrane }\end{array}$ & do & 625 & do \\
\hline chnfrbspg.e00 & radioactive black sand placer & do & 750 & do \\
\hline chnfrhyog.e00 & $\begin{array}{l}\text { high-level, rhyolite-hosted, } \\
\text { precious-metal deposits }\end{array}$ & do & 625 & do \\
\hline chnfstmog.e00 & stockwork molybdenum deposits & do & 625 & do \\
\hline chnfstrvg.e00 & stratiform vanadium deposits & do & 500 & do \\
\hline
\end{tabular}




\begin{tabular}{|c|c|c|c|c|}
\hline Arclnfo interchange-format file name & Deposit type assessed & Source material & $\begin{array}{c}\text { The overall } \\
\text { horizontal } \\
\text { accuracy (+/-) of } \\
\text { the spatial digital } \\
\text { databases, in } \\
\text { meters }\end{array}$ & Reference \\
\hline chnfstsyg.e00 & $\begin{array}{l}\text { stratabound syngenetic deposits } \\
\text { of precious and base metals }\end{array}$ & do & 500 & do \\
\hline chnftextg.e00 & $\begin{array}{l}\text { polymetallic veins in Tertiary } \\
\text { extrusive terrane }\end{array}$ & do & 750 & do \\
\hline chnftuffg.e00 & $\begin{array}{l}\text { precious-metal deposits in } \\
\text { volcanic tuffs }\end{array}$ & do & 500 & do \\
\hline chnfunkng.e00 & $\begin{array}{l}\text { The presence of mineralization is } \\
\text { suggested but definitive data is } \\
\text { not available to indicate the type } \\
\text { or kind. }\end{array}$ & do & 750 & do \\
\hline chnfurang.e00 & vein uranium deposits & do & 625 & do \\
\hline chnfwsvng.e00 & $\begin{array}{l}\text { tungsten stockwork and vein } \\
\text { deposits }\end{array}$ & do & 938 & do \\
\hline \multicolumn{5}{|c|}{ Choteau $1^{\circ} \times 2^{\circ}$ quadrangle, scale $1: 250,000$} \\
\hline chotaulog.e00 & gold lode deposits & $\begin{array}{l}\text { The original published maps were scanned } \\
\text { and vectorized by Optronics Specialty Co., } \\
\text { Inc. to create ArcInfo datasets. }\end{array}$ & 250 & $\begin{array}{l}\text { Earhart and others } \\
\text { (1981b) }\end{array}$ \\
\hline chotaupg.e00 & gold placer deposits & do & 500 & do \\
\hline chotbarvg.e00 & vein deposits of barite & do & 750 & do \\
\hline chotcumog.e00 & $\begin{array}{l}\text { porphyry copper-molybdenum } \\
\text { deposits }\end{array}$ & do & 438 & do \\
\hline chotgrbdg.e00 & greenbed copper-silver deposits & do & 750 & do \\
\hline chotheleg.e00 & $\begin{array}{l}\text { stratabound lead-zinc and } \\
\text { copper-silver deposits in } \\
\text { calcareous quartzite of the } \\
\text { Helena Formation }\end{array}$ & do & 750 & do \\
\hline chotmagg.e00 & titaniferous magnetite deposits & do & 563 & do \\
\hline chotpbzng.e00 & $\begin{array}{l}\text { fracture filling and replacement } \\
\text { lead-zinc deposits }\end{array}$ & do & 438 & do \\
\hline chotpsilg.e00 & $\begin{array}{l}\text { copper-lead-zinc mineralized } \\
\text { veins associated with Proterozoic } \\
\text { Z sills }\end{array}$ & do & 750 & do \\
\hline chotquarg.e00 & $\begin{array}{l}\text { stratabound copper-silver } \\
\text { deposits in gray quartzite }\end{array}$ & do & 1000 & do \\
\hline chottintg.e00 & $\begin{array}{l}\text { polymetallic vein deposits } \\
\text { associated with Tertiary }\end{array}$ & do & 250 & do \\
\hline
\end{tabular}




\begin{tabular}{|c|c|c|c|c|}
\hline Arclnfo interchange-format file name & Deposit type assessed & Source material & $\begin{array}{c}\text { The overall } \\
\text { horizontal } \\
\text { accuracy (+/-) of } \\
\text { the spatial digital } \\
\text { databases, in } \\
\text { meters }\end{array}$ & Reference \\
\hline & intrusives & & & \\
\hline \multicolumn{5}{|c|}{ Dillon $1^{\circ} \times 2^{\circ}$ quadrangle, scale $1: 250,000$} \\
\hline dichlorig.e00 & chlorite deposits & $\begin{array}{l}\text { The original published maps were scanned } \\
\text { and vectorized by Optronics Specialty Co., } \\
\text { Inc. to create ArcInfo datasets. }\end{array}$ & 750 & $\begin{array}{l}\text { Pearson and others } \\
\text { (1990) }\end{array}$ \\
\hline dichromig.e00 & chromite deposits & do & 750 & do \\
\hline digraphig.e00 & graphite deposits & do & 625 & do \\
\hline diironfmg.e00 & bedded iron-formation & do & 750 & do \\
\hline dinickelg.e00 & nickel deposits & do & 750 & do \\
\hline diporphg.e00 & $\begin{array}{l}\text { porphyry copper and } \\
\text { molybdenum }\end{array}$ & $\begin{array}{l}\text { Unpublished raster data files used in } \\
\text { conducting the CUSMAP assessment were } \\
\text { vectorized to create ArcInfo datasets. }\end{array}$ & 250 & $\begin{array}{l}\text { Pearson, Trautwein } \\
\text { and others (1992b) }\end{array}$ \\
\hline diqplacrg.e00 & $\begin{array}{l}\text { placer gold and silver in modern } \\
\text { stream valleys }\end{array}$ & do & 500 & $\begin{array}{l}\text { Pearson and others } \\
\text { (1991) }\end{array}$ \\
\hline diskarng.e00 & skarn deposits & do & 438 & $\begin{array}{l}\text { Pearson, Trautwein } \\
\text { and others (1992b) }\end{array}$ \\
\hline distcuagg.e00 & $\begin{array}{l}\text { Belt-type stratabound copper- } \\
\text { silver deposits }\end{array}$ & $\begin{array}{l}\text { The original published maps were scanned } \\
\text { and vectorized by Optronics Specialty Co., } \\
\text { Inc. to create ArcInfo datasets. }\end{array}$ & 750 & $\begin{array}{l}\text { Pearson and others } \\
\text { (1990) }\end{array}$ \\
\hline disupbzng.e00 & $\begin{array}{l}\text { Sullivan-type stratabound lead- } \\
\text { zinc-silver }\end{array}$ & do & 500 & do \\
\hline ditalcg.e00 & talc deposits & do & 688 & do \\
\hline ditplacrg.e00 & $\begin{array}{l}\text { placer gold and silver in Tertiary } \\
\text { sediments }\end{array}$ & $\begin{array}{l}\text { Unpublished raster data files used in } \\
\text { conducting the CUSMAP assessment were } \\
\text { vectorized to create ArcInfo datasets. }\end{array}$ & 500 & $\begin{array}{l}\text { Pearson and others } \\
\text { (1991) }\end{array}$ \\
\hline diveing.e00 & $\begin{array}{l}\text { vein and replacement deposits of } \\
\text { base and precious metals, barite } \\
\text { and fluorspar }\end{array}$ & do & 375 & $\begin{array}{l}\text { Pearson, Trautwein, } \\
\text { and others (1992a) }\end{array}$ \\
\hline dixaubasg.e00 & $\begin{array}{l}\text { exhalative deposits of gold and } \\
\text { base metals }\end{array}$ & $\begin{array}{l}\text { The original published maps were scanned } \\
\text { and vectorized by Optronics Specialty Co., } \\
\text { Inc. to create ArcInfo datasets. }\end{array}$ & 813 & $\begin{array}{l}\text { Pearson and others } \\
\text { (1990) }\end{array}$ \\
\hline diyecocug.e00 & $\begin{array}{l}\text { Blackbird-type cobalt-copper- } \\
\text { gold }\end{array}$ & do & 750 & do \\
\hline \multicolumn{5}{|c|}{ Wallace $1^{\circ} \times 2^{\circ}$ quadrangle, scale $1: 250,000$} \\
\hline wa250aupg.e00 & placer gold & Lines were selected from the Wallace & 313 & Harrison, \\
\hline
\end{tabular}




\begin{tabular}{|c|c|c|c|c|}
\hline Arclnfo interchange-format file name & Deposit type assessed & Source material & $\begin{array}{l}\text { The overall } \\
\text { horizontal } \\
\text { accuracy }(+/-) \text { of } \\
\text { the spatial digital } \\
\text { databases, in } \\
\text { meters }\end{array}$ & Reference \\
\hline & & $\begin{array}{l}1: 250,000 \text { digital geologic map (Harrison, } \\
\text { Griggs, and others, 2000) that match the } \\
\text { lines representing potential for placer Au } \\
\text { and pasted into a new dataset. Additional } \\
\text { lines were digitized from Harrison, } \\
\text { Cressman and others (1986). }\end{array}$ & & $\begin{array}{l}\text { Domenico, and } \\
\text { Leach (1986a) }\end{array}$ \\
\hline wa250esdg.e00 & epithermal silver & $\begin{array}{l}\text { Selected arcs and polygons were digitized } \\
\text { from paper maps to create ArcInfo datasets. }\end{array}$ & 313 & $\begin{array}{l}\text { Harrison and others } \\
\text { (1986b) }\end{array}$ \\
\hline wa250mvg.e00 & mesothermal veins & do & 250 & $\begin{array}{l}\text { Harrison and others } \\
\text { (1986a) }\end{array}$ \\
\hline wa250pgmg.e00 & platinum group metal & do & 188 & $\begin{array}{l}\text { Harrison and others } \\
(1986 b)\end{array}$ \\
\hline wa250pmtg.e00 & porphyry molybdenum-tungsten & do & 438 & do \\
\hline wa250scsg.e00 & $\begin{array}{l}\text { stratabound copper-silver } \\
\text { deposits }\end{array}$ & $\begin{array}{l}\text { Lines were selected from the Wallace } \\
\text { 1:250,000 digital geologic map (Harrison, } \\
\text { Griggs, and others, 2000) that match the } \\
\text { lines representing potential for stratabound } \\
\text { Cu-Ag and pasted into a new dataset. } \\
\text { Additional lines were digitized from } \\
\text { Harrison, Domenico and Leach (1986). }\end{array}$ & 500 & $\begin{array}{l}\text { Harrison, } \\
\text { Domenico, and } \\
\text { Leach }(1986 b)\end{array}$ \\
\hline wa250sslg.e00 & $\begin{array}{l}\text { Sullivan type stratabound lead- } \\
\text { zinc-silver }\end{array}$ & $\begin{array}{l}\text { Selected arcs and polygons were digitized } \\
\text { from paper maps to create ArcInfo datasets. }\end{array}$ & 375 & $\begin{array}{l}\text { Harrison, Cressman, } \\
\text { and others (1986) }\end{array}$ \\
\hline
\end{tabular}

